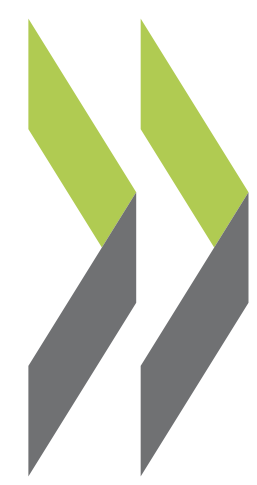

OECD Economics Department Working Papers No. 500

\title{
Labour Market \\ Performance, Income Inequality and Poverty in OECD countries
}

Jean-Marc Burniaux, Flavio Padrini, Nicola Brandt 
Organisation de Coopération et de Développement Economiques

Organisation for Economic Co-operation and Development

17-Jul-2006

ECONOMICS DEPARTMENT

English text only

\section{LABOUR MARKET PERFORMANCE, INCOME INEQUALITY AND POVERTY IN OECD COUNTRIES}

Economics Department Working Paper No. 500

By

Jean-Marc Burniaux, Flavio Padrini and Nicola Brandt

Note: The Annexes to the OECD Economics Department Working Paper No. 500 are only available on the Economics Department Website at www.oecd/org/eco/working_Papers

All Economics Department Working Papers are now available through OECD's Internet website at http://www.oecd.org/eco 


\begin{abstract}
Labour market performance, income inequality and poverty in OECD countries

There have been concerns that employment-enhancing reforms along the lines of the 1994 OECD Jobs Strategy could inadvertently lead to increased income inequality and poverty. This paper focuses on the impact of institutions and redistributive policies on inequality and poverty with the view of assessing whether a trade-off between better labour market performance and equity has taken place in OECD countries, notably in the 1990s. During this period, reductions of unemployment have been associated with rising wage dispersion for workers in most OECD countries. Nevertheless, no clear general trend appears for total disposable income inequality and relative poverty among the total population. These developments suggest that gains from higher employment have in general offset the impact of rising wage dispersion. A preliminary econometric analysis for the period 19782000 fails to detect any robust relationship between labour market institutions/policies and inequality as measured by the Gini coefficient.
\end{abstract}

Please note that annexes are only available on the OECD Economics Department Website at: www.oecd.org/eco/Working Papers.

JEL: I38; J38; J58; J68

Keywords: employment; unemployment; institution; income distribution; poverty.

\title{
RÉSUMÉ
}

\section{Performance du marché de l'emploi, inégalité des revenus et pauvreté dans les pays de l'OCDE}

Des inquiétudes ont été souvent exprimées par la suite selon lesquelles les réformes visant à stimuler l'emploi selon la base de l'Étude de l'OCDE sur l'Emploi publiée en 1994 pourrait en fait se traduire par une augmentation des inégalités des revenus et de la pauvreté. Ce document de travail a pour objet l'impact des institutions et des politiques de redistribution sur l'inégalité et la pauvreté avec la perspective d'évaluer dans quelle mesure un arbitrage entre un meilleur fonctionnement du marché de l'emploi et l'équité des revenus s'est manifesté dans les pays de l'OCDE, notamment, dans les années 90 . Au cours de cette période, le chômage a été réduit dans une majorité de pays de l'OCDE et cela simultanément à une augmentation de la dispersion des salaires des travailleurs. Néanmoins, en ce qui concerne l'inégalité des revenus disponibles et la pauvreté relative au niveau de l'ensemble de ménages, il n'est pas possible de dégager une tendance générale. Il semblerait donc que les gains de redistribution associés à l'augmentation de l'emploi ont été suffisants, en général, pour compenser l'augmentation des inégalités salariales. Une analyse économétrique préliminaire pour la période 1978-2000 ne permet pas d'identifier des relations robustes entre les institutions et les politiques du marché de l'emploi, d'une part, et l'inégalité des revenus mesurée par l'indice de Gini, d'autre part.

Les annexes sont disponibles uniquement sur le site web du Département des Affaires économiques de l'OCDE: www.oecd.org/eco/Documentsdetravail.

Classification JEL: I38; J38; J58; J68

Mot clefs: emploi, chômage; institution; distribution des revenus; pauvreté.

Copyright $@$ OECD, 2006

Application for permission to reproduce or translate all, or part of, this material should be made to: Head of Publications Service, OECD, 2 rue André-Pascal, 75775 PARIS CEDEX 16, France. 


\section{TABLE OF CONTENTS}

Labour Market Performance, Income Inequality and Poverty in OECD Countries................................ 5

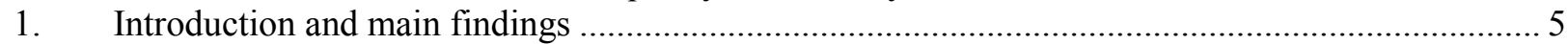

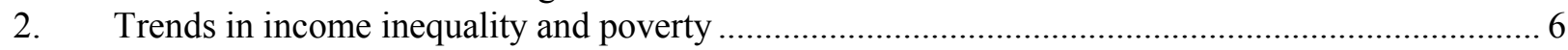

3. Labour market performance and trends of inequality and poverty........................................... 9

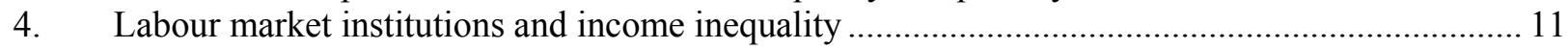

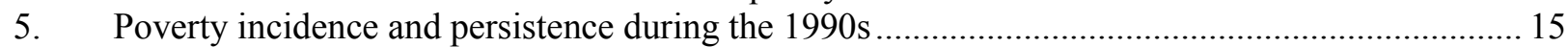

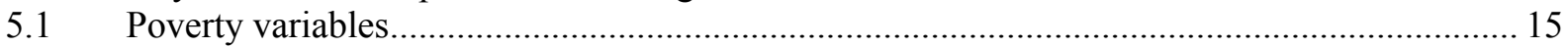

5.2 Poverty incidence and dynamics: cross-country differences ............................................... 16

5.3 Individual and household characteristics and poverty risk ..................................................... 18

$5.4 \quad$ Labour market performance and poverty risk ..................................................................... 19

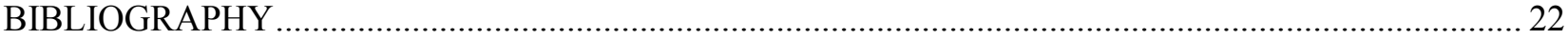

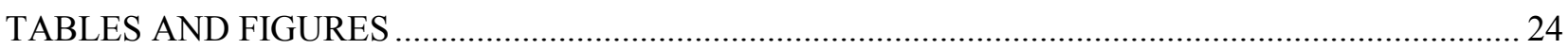

Boxes

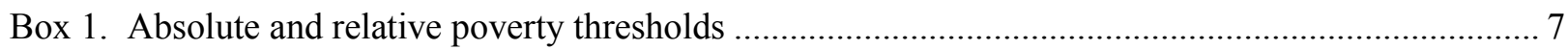

\section{Tables}

1. Cross-correlations of inequality and poverty measures

2. Trends of unemployment and overall income inequality

3. Trends of unemployment and relative poverty

4. Trends of unemployment and gross earnings inequality for the whole population

5. Trends of unemployment and gross earning inequality in three bottom earnings deciles of the population

6. Trends of unemployment and gross earnings inequality for the employed population

7. Trends of unemployment and transfers' redistributive impact

8. Trends of unemployment and taxes' redistributive impact

9. Correlations of inequality and poverty measures with labour market aggregates

10. Cross-country time-series reduced-form estimates of income inequality models

11. Regression of the Gini coefficient against policies/institutions, 1978-2000

12. Mean and standard deviation of Gini coefficient and explanatory variables, 1978-2000

13. Specification tests for the Gini coefficient model

14. Regression of 9th-to-1st decile ratio against policies/institutions, 1978-2000

15. Indicators of poverty risk

16. Cross-correlations of poverty measures

17. Income mobility of 1994-wave poor exiting poverty in 1995 wave

18. Relative risk of poverty

19. Correlations of poverty measures with labour market aggregates

20. Regression of poverty rate against policies/institutions, 1978-2000 


\section{$\mathrm{ECO} / \mathrm{WKP}(2006) 28$}

\section{Figures}

1. Indicators of income inequality and relative poverty, 2001

2. Evolution of disposable income inequality across OECD countries

3. Evolution of relative poverty rates across OECD countries

4. Relative poverty risk profile by age group

5. Relative poverty risk by working status, 1994-2001 
ECO/WKP(2006)28

\title{
LABOUR MARKET PERFORMANCE, INCOME INEQUALITY AND POVERTY IN OECD COUNTRIES
}

\author{
by Jean-Marc Burniaux, Flavio Padrini and Nicola Brandt ${ }^{1}$
}

\section{Introduction and main findings}

1. The 1994 OECD Jobs Strategy stressed the importance of strong employment growth and declining unemployment for improving equity and reducing the need for public income support in OECD countries (OECD, 1994). Accordingly, many of the Jobs Strategy's recommendations have underlined the need for fundamental reforms of labour market institutions/policies with the aim of raising incentives for individuals to work and for firms to hire. Nevertheless, an early review of member countries' reform experiences suggested that several of them had failed to implement comprehensive changes because of concerns that these could lead to increasing income inequality and poverty (OECD, 1997).

2. The relationship between labour market policies/institutions and inequality or poverty is complex. On the one hand, a growing body of analysis provides clear evidence about the negative impact of some institutions and policies on labour market performance. Reforms that reduce structural unemployment or raise employment can contribute to reduce income inequality and poverty. On the other hand, some of these institutions and policies could directly reduce income inequality and poverty.

3. This paper focuses on the impact of labour market performance, institutions and redistributive policies on inequality and poverty. It contains two main sections. Section 2 describes the main evolution of inequality and poverty during past decades across OECD countries for which comparable data are available and attempts to identify the main components of this evolution in terms of income sources. It also explores econometrically the relationship between labour market policies/institutions and income inequality. Section 3 documents cross-country differences in poverty dynamics and income mobility of the poor during the 1990s. It also examines the relationship between individual and household characteristics and risk of poverty incidence and persistence. Finally, it provides some statistical evidence on the relationship between labour market performance and poverty across OECD countries and explores econometrically the link between labour market institutions/policies and poverty rates.

4. The main findings are as follows:

- Both inequality at the level of disposable income and the relative poverty rate have remained broadly constant since the mid-1990s on average in the OECD countries for which data are available, after rising during the previous decade.

1. Jean-Marc Burniaux (jean-marc.burniaux@oecd.org) and Flavio Padrini (flavio.padrini@oecd.org) are economists in the Structural Policy Analysis Division 2 of the OECD Economic Department. Nicola Brandt (Nicola.Brandt@bmf.bund.de) contributed to the initial stage of this research and is now an economist at the German Ministry of Finance. The authors would like to thank Romain Duval and Florian Pelgrin for advices about the econometric methodology and Sveinbjörn Blöndal, Mike Feiner, John Martin, Michael Förster and Marco Mira d'Ercole for valuable comments. Statistical assistance was provided by Catherine Chapuis-Grabiner. The views expressed in this paper are those of the authors and do not necessarily reflect those of the OECD or its member countries. 
- During this period, reductions of unemployment have been associated with rising wage dispersion for workers. Nevertheless, no clear general trend appears for total disposable income inequality and relative poverty among the total population. These developments suggest that gains from higher employment have in general offset the impact of rising wage dispersion. Indeed, simple correlations indicate a significant statistical association between improved labour market performance - especially of females - and lower inequality and poverty.

- A preliminary econometric analysis suggests that a stronger bargaining power of trade unions is associated with lower relative poverty and income inequality when this is measured by an indicator giving more weight to the tails of the income distribution (the $9^{\text {th }}$-to- $1^{\text {st }}$ decile ratio). This result could possibly be explained by the unions' role in compressing the wage distribution and in limiting the extent of the working poor. Moreover, a negative relationship emerges between the tax wedge and relative poverty, probably because the corresponding tax revenues are used to finance social programmes.

- However, the analysis fails to detect a role for the unemployment benefit system in affecting inequality/poverty and, in general, any robust relationship between labour market institutions/policies and inequality as measured by the Gini coefficient, which gives more weight to middle parts of the income distribution. Whether this indicates that institutions/policies have a limited effect on the overall income distribution or it is the result of insufficient data availability on both inequality and policies is an issue deserving further examination in future analysis.

- Regarding poverty dynamics during the 1990s, a non-negligible share of individuals have suffered chronic poverty - defined as having average income below average poverty threshold during an extended period of time - in most countries with high poverty rates. In some of these countries, like Spain, and to a lesser extent Italy, chronic poverty has mostly taken the form of multiple poverty spells.

- Good labour market performance is in general associated with lower poverty incidence, a lower risk of entry into poverty and a higher probability of exit. By contrast, unemployment especially long-term unemployment - is correlated with a higher risk of entering into poverty. Finally, the presence of second worker in the family, even working part-time, considerably reduces the risk of poverty.

\section{Trends in income inequality and poverty}

5. This section describes developments in income inequality and poverty for a number of OECD countries, focusing on how trends have changed after the mid-1990s. In particular, the section explores whether improvements in labour market performance observed in many OECD countries have been systematically associated with changes in income inequality and poverty. It also decomposes changes in income inequality by main income sources: labour earnings, other earnings (capital and selfemployment) and transfers/taxes.

6. Inequality is multifaceted by nature, and alternative measurements of inequality and poverty yield different information on the income distribution. The measurement of poverty that is used in this study is relative rather than absolute (see Box 1 for the pros and cons of relative and absolute poverty). The analysis is based on alternative measures of income inequality and relative poverty (see also Annex 1):

- Income inequality is measured by: $i$ ) the Gini coefficient that provides a relatively neutral measurement of inequality, as it gives equal weight to different parts of the distribution; and ii) 
the ratio of $9^{\text {th }}$-to-1st income deciles that is more sensitive to changes in the two extremes of the distribution.

- Relative poverty is measured by the proportions of individual with income either below 50 or $60 \%$ of the median income. ${ }^{2}$

7. The decomposition of income inequality among different income sources is based on three different methods applied to the Gini coefficient: $i$ ) additive; ii) the Shorrocks' method; and iii) subtractive (see Annex 1 for more details).

8. Given the different measures used in the literature, the emphasis in this report is put on checking the validity of the results across alternative indicators and methodologies. Additionally, there are alternative sources of household income data (see Annex 1) that sometimes lead to diverging outcomes. This study uses data from Förster and Mira d'Ercole (2005) as a benchmark. These data have been collected by the OECD based on common assumptions and methodology and provide some guarantee of quality and comparability across countries. Other datasets have been used for testing the robustness of the results and building up more complete time series.

\section{Box 1. Absolute and relative poverty thresholds}

The choice of the poverty threshold, i.e. of the income threshold below which a person is considered poor, crucially affects the calculation of poverty rates. Two categories of thresholds are commonly used (Foster, 1998): a) absolute poverty thresholds where the cut-off real income level is determined according to the costs of a basket of basic "necessities" without reference to the income distribution of the population; b) relative poverty thresholds where the cut-off real income level is determined as a percentage of an indicator of the average "standard of living", typically the median or the mean of the income distribution, and, therefore, changes over time and across countries.

Both absolute and relative poverty thresholds have benefits and drawbacks. A drawback shared by both thresholds is the high degree of judgement used for their calculation (see e.g. Citro and Michael, 1995).

The calculation of absolute thresholds leads to some difficult issues, especially when international comparisons are carried out. Conceptually, it is controversial to use the same basket of basic necessities across countries. Moreover, statistical issues are quite problematic when extending the absolute threshold calculated for a benchmark country to all the other countries under analysis as this typically requires the use of an "appropriate" exchange rate, typically the purchasing-power-parity (PPP) exchange rate. ${ }^{3}$ However, existing PPP exchange rates that have been calculated to compare GDP or national consumption levels in different countries are not well suited for comparing poverty cut-offs (Smeeding et al., 2000, Deaton, 2003, and Reddy and Pogge, 2005). ${ }^{4}$ Furthermore, the choice of a price index to update absolute thresholds within each country over time raises further difficulties. Finally, absolute thresholds have to be adjusted in real terms over the long run to reflect changes in basic needs. ${ }^{5}$

Similarly, relative poverty rates are affected by other difficult problems. The relative poverty cut-offs, indeed, are subject to the arbitrary choice of the percentage of the average-living-standard indicator used to calculate them. Moreover, the relative poverty rate is dependent on changes affecting the overall

2. The poverty indicators are based on disposable income rather than consumption. Therefore, they overlook that, to a different extent in OECD countries, merit goods or services like health or education are provided for free or below cost by the public sector, often on a means-tested basis. Moreover, the regressive/progressive nature of the indirect-tax-rate schedule could drive a wedge between poverty calculated on a disposable-income basis and that calculated on a consumption basis. These issues are not tackled in this paper. 
distribution and might not closely reflect the evolution of the standard of living of the poor.

Despite these problems, this paper calculates poverty rates using relative thresholds, e.g. as a percentage of median income, because of the problem of defining common level of absolute thresholds valid across a large number of countries. This is in line with most existing cross-national time-series studies. The interpretation of such a relative concept should take into account the fact that relative poverty may increase simply because median income increases without necessarily implying a deterioration of the purchasing power of the poor.

1. One way of avoiding the choice of benchmark countries as well as the use of PPP exchange rates would be to rely on national (official or unofficial) absolute thresholds, which should be available in most OECD countries over extended periods of time. Nevertheless, this method would ensure international comparability of poverty rates only if basic human requirements implicit in the calculation of national thresholds were identical across countries, which is not warranted.

2. Real adjustment of absolute thresholds also avoids unrealistic drops of poverty rates in countries with rapidly growing overall income. This adjustment is desirable as long as growing income has enlarged the range of goods and services perceived as basic by the population. In contrast with absolute thresholds where the adjustment is ad hoc, relative poverty thresholds adjust in real terms automatically over time in line with median real income. For example, in the present study the relative poverty thresholds of fast growing countries like Ireland and Spain have risen at a fast pace in real terms since the mid-1980s. As another example, in the absence of such an adjustment, a constant real threshold in Portugal would imply an unrealistic drop of poverty incidence from 19\% in 1979-1980 to 3\% only in 2000 according to the data collected by Förster and Mira d'Ercole (2005).

3. For example, a broad-based drop of income at all deciles would raise poverty rates calculated with absolute thresholds but would leave unchanged those calculated with relative thresholds, despite that the poor have almost certainly experienced a worsening of their standard of living (Madden, 2000).

9. At the beginning of the current decade, income inequality, as measured by the Gini coefficient, was comparatively lower in Northern European countries and relatively higher in Southern European countries, English-speaking countries, low-income OECD countries and Japan (Figure 1). ${ }^{3}$ Relative poverty, measured as the proportion of the population with income below $50 \%$ of the current median income, follows a similar pattern across countries, ranging from around $4 \%$ in the Czech Republic to more than $20 \%$ in Mexico.

[Figure 1. Indicators of income inequality and relative poverty, 2001]

10. Household inequality at the level of disposable income, as measured by the $9^{\text {th }}$-to- $1^{\text {st }}$ income decile ratio, as well as relative poverty rates have remained broadly stable since 1994 on average in the OECD, after rising during the previous decade (Figures 2 and 3).

\section{[Figure 2. Evolution of disposable income inequality across OECD countries]}

\section{[Figure 3. Evolution of relative poverty rates across OECD countries]}

11. Cross-correlations among inequality and poverty measures are quite high (Table 1) so that the above ranking is broadly similar for the other indicators (Figure 1). A few exceptions are worth noticing, though. While the United Kingdom has a higher Gini coefficient than the average of the OECD countries, the other indicators for this country are not very far from the OECD average, suggesting that compared to other countries in the United Kingdom a significant part of inequality is due to income differences in the

3. This confirms the results of previous analyses (OECD, 2005a and Förster and Mira d'Ercole, 2005). See also results in Atkinson (2004) based on the Luxembourg Income Study (LIS) database. 
central part of the income distribution. ${ }^{4}$ The opposite is true for Japan and, especially, Ireland where a greater part of income dispersion is related to the bottom part of the distribution. ${ }^{5}$

\section{[Table 1. Cross-correlations of inequality and poverty measures]}

\section{Labour market performance and trends of inequality and poverty}

12. Given the use of multiple data sources and indicators, the emphasis in this section is put on outcome sensitivity, as summarised in synthetic tables. These tables group countries according to their evolution of inequality and poverty, on the one hand, and unemployment, on the other hand. An increase (decrease) of inequality or poverty is considered when a majority of indicators and sources agree in identifying clearly an increase (decrease). ${ }^{6}$ No change in inequality or poverty corresponds to a situation where the observed changes are small and/or alternative indicators and sources generate conflicting outcomes. $^{7}$ Annex 2 provides all the detailed results for the inequality and poverty indicators by data source on which the synthetic tables are based.

13. No general relationship emerges between unemployment and inequality trends (Table 2). After 1993-1994, among countries where unemployment dropped, inequality has been reduced in four of them, but increased in five others. Among countries with rising unemployment, the Czech Republic, Japan and Luxembourg have also witnessed rising inequalities whereas the opposite is true for Austria and Germany. No clear relationship appears before 1993 either. The link between unemployment trends and changes in relative poverty is also weak (Table 3 ).

\section{[Table 2. Trends of unemployment and overall income inequality]}

\section{[Table 3. Trends of unemployment and relative poverty]}

14. In contrast with household disposable income, there is a clear positive relationship between changes in unemployment and gross earnings inequality for the whole population. ${ }^{8}$ Gross earnings inequality for the whole population has declined in the majority of the countries witnessing a fall of unemployment in the 1990s, in some cases reversing or terminating upward trends of previous years (Table 4). ${ }^{9}$ In countries where unemployment increased during the $1990 \mathrm{~s}$, developments in earnings inequality were less uniform. However, overall earnings inequality increased in Japan and the Czech Republic during this period, thus showing that in these countries rising unemployment has gone hand in hand with

4. Portugal shows a higher ranking as far as the median-to-1st decile ratio is concerned. However, both the 9th-to-1st decile ratio and the poverty rate remain relatively high.

5. Similarly to Ireland and Japan, Austria records lower inequality based on the overall Gini coefficient than with indicators giving more weight to inequalities in the bottom part of the income distribution. However, in Austria the values of all indicators remain low compared with most other countries.

6. See Annex 1 for the thresholds and criteria chosen in assessing trends of inequality and poverty indicators and unemployment rates.

7. See Atkinson et al. (2000) on the methodological issues arising when carrying out trend analysis of inequality using several datasets.

8. This section is based on three alternative decomposition methods of the impact of sources of income on overall inequality that are described in Annex 1. The population considered covers all households and, therefore, the contribution of gross labour earnings to overall inequality takes into account also nonworking households with zero gross labour earnings.

9. See also results in Förster and Mira d'Ercole (2005) and OECD (2005a). 
increased inequalities in labour income of the population. When restricting the analysis to the population in the three bottom earnings deciles (Table 5), gross earnings inequality has declined in all countries experiencing a reduction in unemployment, except for Sweden. These results suggest that employment gains could have contributed to reduce labour market income inequalities during the past decade, especially at bottom deciles.

[Table 4. Trends of unemployment and labour earnings inequality for the whole population]

[Table 5. Trends of unemployment and labour earnings inequality of the three bottom earnings deciles of the population]

15. In countries with improved labour market performance, the decline in gross earnings inequality for the population as a whole has been accompanied by increased earnings inequality for the employed population (Table 6). Indeed, in almost all countries with falling unemployment rates after 1993-94, gross earnings inequality among workers has risen. The reason why this has not translated into greater inequality for the population as a whole is the equalising effect of the associated employment gains.

\section{[Table 6. Trends of unemployment and labour earnings inequality for the employed population]}

16. In many countries, overall income distribution remained broadly unchanged despite a decline in gross earnings inequality for the population as a whole as the equalising effects of taxes and transfers has been reduced, possibly as a result of the reforms. ${ }^{10}$ Indeed, the redistributive impact ${ }^{11}$ of transfers has weakened after 1993-94 in a majority of countries with falling unemployment rates, while the opposite relationship - rising distributive power of transfers together with rising unemployment - was common in many countries before 1993-94 (Table 7). By contrast, trends of the redistributive impact of taxes show marked differences across countries during the 1990s probably because of the different design of tax reforms carried out across them (Table 8). Before 1993-94, trends were more uniform at least in countries with declining unemployment, as in a majority of them the redistributive impact of taxes increased.

\section{[Table 7. Trends of unemployment and redistributive impact of transfers]}

\section{[Table 8. Trends of unemployment and redistributive impact of taxes]}

17. On the basis of simple bivariate correlation analysis, better labour market performance, notably for females, is associated with lower inequality, especially when measured with the Gini index (Table 9). Participation and employment rates are negatively correlated with the Gini index and the $9^{\text {th }}-$ to $-1^{\text {st }}$ decile ratio, but their negative correlation with the median-to- $1^{\text {st }}$ decile is not significant. The unemployment rate is positively correlated with the inequality indicators, significantly so with the Gini index and the $9^{\text {th }}$-to- $1^{\text {st }}$ decile ratio. Female labour market aggregates show stronger correlations with inequality indicators than male ones.

\section{[Table 9. Correlations of inequality and poverty measures with labour market aggregates]}

18. This section has illustrated that, although there appears to be little relation between changes in unemployment and those in inequality/poverty, the correlation in levels is often statistically significant. This suggests that most of the association among these variables rests on cross-national correlations. By

10. See Annex 2 for a detailed analysis of trends of shares, inequality and redistributive impact of taxes and transfers before and after the mid-1990s both for the whole population and for the three bottom income deciles.

11. See Annex 1 for a definition of redistributive impact. 
contrast, within-country changes in labour market performance can go hand in hand with different trends for income dispersion and relative poverty. One important reason for this outcome could be that better labour market performance could be achieved through reforms of institutions/policies that affect income dispersion in many different directions. These issues are the focus of the next section where a multivariate analysis of the relationship between labour market institutions/policies and inequality is carried out.

\section{Labour market institutions and income inequality}

\section{Theoretical framework and previous empirical findings}

19. Analysing the impact of labour market institutions and policies on inequality in a macroeconomic framework represents a relatively new line of research. As shown by some recent papers (Atkinson and Brandolini, 2004, and Checchi and Garcia-Penalosa, 2005), theoretical models could be used to disentangle the different - often opposing - channels characterising the relationship between institutions/policies and inequality. Redistributive policies, such as embedded in unemployment or social assistance benefits, should exert a direct negative impact on disposable income inequality of the whole population through the payment of benefits to the unemployed or the inactive with no labour income. Labour market institutions, like trade unions, could have a negative impact on wage dispersion ${ }^{12}$ and a positive one on the labour share, thus contributing to lower inequalities. ${ }^{13}$ On the other hand, the same policies and institutions could increase unemployment or reduce participation in the labour force, either directly or through the tax increase needed to finance them. By raising between-group inequality, they could contribute widening the disposable income distribution of the whole population.

20. Thus, policy and institutional changes have a theoretically ambiguous effect on inequality. Several additional factors make empirical analysis in this area difficult, including the lack of good quality annual data on inequality for sufficiently long time periods, ${ }^{14}$ the possibility of omitted variables ${ }^{15}$ and the fact that institutions and policies are likely to affect various segments of the income distribution in different ways, making the results sensitive to the choice of the inequality indicator.

21. A number of recent empirical cross-country/time-series studies aim at identifying and quantifying the relationship between institutions/policies and income inequality in OECD countries (see Table 10 for a synthetic review of the empirical literature). While there is no overall consensus across them, in general

12. A strand of the literature tries to assess the impact of labour market institutions - notably unionisation, wage centralisation and minimum wages - on wage inequality. See Blanchflower and Slaughter (1999) for a review and Koeniger et al. (2004) for a recent empirical assessment. These studies in general conclude that certain labour market institutions can have a negative impact on wage inequality.

13. The negative impact of the labour share on income inequality rests on the evidence that labour income distribution is more compressed than the capital income distribution.

14. See Atkinson and Brandolini (2001) for the issues involved in the use of "secondary" data-sets on inequality.

15. For example, the distribution of disposable income could be affected by a number of features of countries' tax systems: the progressivity of the tax rate schedule; the generosity of basic allowances; the differential tax treatment of capital, pension, dependent labour and independent labour income; the integration (or lack of integration) between the corporate and personal income tax systems; and the different impact of tax relieves on different deciles of the income distribution. See OECD (2006) for a discussion and some illustrations. Nonetheless, estimating the impact of these policies on income inequality at the aggregate level is problematic because long time series for policy indicators related to the above features of tax systems are not available. 
they indicate that several institutions may contribute to reduce income inequality. However, in some studies the income definitions in the calculation of the inequality indicators are neither consistent across countries nor over time. ${ }^{16}$ Moreover, a check on the robustness of the results to different specifications, notably to the inclusion of country effects, or to a different choice of the inequality indicator as dependent variable and of different institutions as explanatory variables is often missing. Finally, the range of institutions and policies included in the specifications is often limited.

\section{[Table 10. Previous studies on cross-country time-series reduced-form estimates of income inequality models]}

22. The following sub-sections aim at providing further pooled cross-country/time series econometric evidence on the relationship between policies/institutions and inequality. Compared with existing studies, the econometric analysis addresses simultaneously a number of different issues. First, a consistent definition of income is employed for the calculation of the inequality indicators across all countries and years. Moreover, the robustness of the results is assessed across different inequality indicators, equation specifications and estimation methods.

\section{The econometric specification}

23. The econometric specifications in this analysis can be interpreted as reduced forms of structural models and include both policies/institutions and a number of controls as follows:

$$
\text { [1] } \mathrm{INEQ}_{\mathrm{it}}=\mathbf{X}_{\mathrm{it}} \boldsymbol{\beta}+\mathbf{C}_{\mathrm{it}} \boldsymbol{\gamma}+\delta_{\mathrm{i}}+\lambda_{\mathrm{t}}+\varepsilon_{\mathrm{it}}
$$

where $\mathrm{i}$ and $\mathrm{t}$ are the country and time subscripts, respectively; INEQ is an inequality indicator; $\mathbf{X}$ is a $1 \mathrm{xK}$ vector of policies/institutions and $\boldsymbol{\beta}$ a Kxlvector of related parameters; $\mathbf{C}$ is a $1 \times \mathrm{xL}$ vector of controls and $\boldsymbol{\gamma}$ is a Lx1 vector of related parameters; $\delta$ stands for the country effect; $\lambda$ denotes the time effect; and $\varepsilon$ is an error term.

24. In the baseline regression, the dependent variable is the Gini coefficient as in most of previous empirical studies. Robustness of the results to the use of the $9^{\text {th }}$-to- $1^{\text {st }}$ ratio as dependent variable is also carried out. Explanatory variables in the baseline specification include policies/institutions and controls that the theoretical macroeconomic literature has found to affect income distributions. Thus, policies/institutions are an index of generosity of the unemployment benefit system, an index of the trade union bargaining power (union density) and the tax wedge. ${ }^{17}$ As discussed above, the impact of these policies/institutions is theoretically ambiguous. Other policies expected to influence the income distribution like active labour market spending and social expenditures other than in labour market programmes (together with the output gap controlling for the cyclical component of these variables) are included in separate regressions.

16. Measurement errors in the dependent variable do not lead to inconsistent estimates as long as they are independent of the regressors. However, this condition is unlikely to hold in regressions with income inequality as dependent variable. For example, the difference between gross and disposable income depends on tax variables, which are sometimes included among the regressors or are strongly related to many of the regressors in these models (for example government expenditures or social benefits).

17. See Annex 3 for more details on the definitions and sources of the regressors. 
25. The baseline specification also includes the following controls: the (log of) capital-labour ratio and average years of education, the latter being a proxy of the relative supply of skilled labour. Checchi and Garcia-Penalosa (2005) show that both variables affect the capital share. Since capital income is in general more unequally distributed than labour income, inequality would also be affected as a result. However, the signs of their impact on the capital share, and hence on inequality, depend on the elasticity of substitution between capital and labour. ${ }^{18}$ Moreover, a rise in the relative supply of skilled labour could affect inequality through lowering the relative wage of skilled workers and, through this channel, contributing negatively to income dispersion.

26. Furthermore, Atkinson and Brandolini (2004) emphasise a hump-shaped link between the share of skilled workers and inequality. At low levels, an increase of the share of skilled workers raises betweengroup inequality. At the same time, within-group inequality could rise if the incomes of skilled workers are more unequally distributed than those of the unskilled. At high levels, however, a further increase of the share of the skilled would reduce between-group inequality and this could counteract any possible rise of within-group inequality.

\section{Empirical results}

27. The above model is estimated for a sample of 18 OECD countries over the period 1978-2000. ${ }^{19}$ Assuming no country or time heterogeneity in the data, unemployment benefits, union density and the tax wedge appear to reduce inequality (Table 11, column 1 ). ${ }^{20}$ Also, average years of education seem to impact negatively on the Gini coefficient. Moreover, the capital/labour ratio shows a significantly positive impact on inequality.

\section{[Table 11. Regression of the Gini coefficient against labour market institutions/policies]}

28. However, failure of controlling for country heterogeneity when it exists could lead to biased results (see for example Moulton, 1987). On the other hand, including country fixed effects in the model eliminates the possibility of exploiting between-country variability of the dependent and explanatory variables in the econometric estimation. Simple variability analyses show that between-country variability represents the most important source of total variability for both the Gini coefficient and the explanatory variables, while within-country variability is typically small (Table 12).

\section{[Table 12. Mean and standard deviation of Gini coefficient and explanatory variables]}

29. Testing the significance of country and time fixed effects is, therefore, important. In Table 13, F-tests show that country- and time-fixed effects are jointly significant and that each set of these effects is significant given the presence of the other. Therefore, the results of these tests suggest that including

18. The assumption of their baseline model specification is that the production function is of the constantelasticity-of-substitution (CES) type with the elasticity between capital and labour being less than 1 . This specification allows variable capital and labour shares. Using this assumption, the authors show that an increase in the capital/labour ratio leads to a lower capital share and, thus, to lower inequality.

19. See notes to Tables 11 and 14-15 for the countries included in the panel. The panel is unbalanced as the number of observations differs across countries. In the estimation with country-fixed effects, two different country dummies have been used for Germany before and after 1990 while the observation for this country/year has been removed from the sample.

20. A number of Breusch-Pagan-type heteroskedasticity tests were carried out and in general they rejected the null hypothesis of absence of heteroskedasticity in the residuals. Therefore, robust standard errors were used. 
country- and time-fixed effects leads to a better specification compared with models with no heterogeneity. Thus, the most preferred specification is the model with country- and time-fixed effects (Table 11, column 2). In columns (4)-(5), robustness of the results is checked against different specifications, while in column (6) 5-year averages are used to limit the influence of measurement errors. Finally, in column (3) estimates of the model with country-random effects are reported.

\section{[Table 13. Specification tests for Gini coefficient model]}

30. Using the most preferred specification, the coefficients of policies/institutions and of average years of education are not significant and some of them even change sign (Table 11, column 2). The coefficient of the capital/labour ratio now has a significantly negative sign. These results are mostly confirmed in the model with country random effects (column 3). In column 4, social expenditures (net of labour market programmes) are included in the regression with country-fixed effects and its impact appears negative although not significant while ALMP spending in column 5 shows a significantly negative sign but a very low coefficient. ${ }^{21}$ Finally, the model was estimated with variables averaged over a 5 -year period (column 6) ${ }^{22}$ and also in this case no significant impact is detected.

31. The sensitivity of these results was assessed using a different inequality indicator as a dependent variable, the $9^{\text {th }}$-to- $1^{\text {st }}$ decile ratio, which, as discussed above, gives more weight to the tails of the income distribution (Table 14). Assuming the absence of country or time heterogeneity yields results very similar to the ones from the regression with the Gini coefficient as dependent variable (Table 14, column 1). In particular, policies /institutions appear to impact negatively on inequality.

\section{[Table 14. Regression of the $9^{\text {th }}-$ to- $1^{\text {st }}$ decile ratio against labour market institutions/policies]}

32. However, F-tests (available on request) show that country- and year-fixed effects are jointly significant. Moreover, country-fixed effects are significant given year-fixed effects. Nevertheless, the opposite does not hold so that specifications without year-fixed effects were preferred. Furthermore, the Hausman (1978) test suggests that the model with country random effects should convey consistent estimates. ${ }^{23}$ Therefore, although results using all specifications are shown, the model with country-random effects was the most preferred specification when using the $9^{\text {th }}$-to- $1^{\text {st }}$-decile ratio as dependent variable (column 2).

33. When this specification is estimated, only the coefficient of union density remains significantly negative (Table 14, column 2). This result is robust also across other specifications (columns 3-6). ${ }^{24}$ Furthermore, the coefficient of social expenditures is significantly negative (column 4), while the impact of

21. In the regression with social spending, the tax wedge was excluded to limit collinearity problems. Moreover both social spending and ALMP spending are affected by the cycle. Therefore, the output gap is included in the regressions so that the coefficients on the two policy variables could be interpreted as the impact of permanent changes in these variables.

22. The estimation sample for this regression is composed of five periods: 1976-1980, 1981-1985, 1986-1990, 1991-1995, and 1996-2000. Because of missing data, the averages are often calculated with less than five years of data.

23. If the country effects are uncorrelated with the other explanatory variables, GLS estimation of the model with random effects is more efficient than the one with fixed effects. However, if the country effects are correlated with the other regressors included in the model, the random-effect GLS estimator is not consistent. The null hypothesis of the Hausman (1978) specification test is that the coefficients of the random- and fixed-effects models are equal.

24. The negative sign of the union density coefficient is also robust to the inclusion of year-fixed effects in the specifications with country-random or country-fixed effects (results available on request). 
ALMP spending is negative but not significant (column 5). In column 6, the model is estimated with 5-year averages and, besides union density, also unemployment benefits and the tax wedge show a statistically significant negative impact on the $9^{\text {th }}$-to- $1^{\text {st }}$ decile ratio.

34. In general, the regression analysis in this sub-section detects only a few robust relationships between indicators of inequality and policies/institutions. The bargaining power of unions seems to limit differences between the extremes of the income distribution. Also, social expenditures (other than in labour market programmes) appear to have a role in limiting income differences between the tails, probably for their role in supporting individuals with low incomes. ALMP spending shows a negative, but very weak, mpact on the Gini coefficient, maybe as a result of the role of training programmes in reducing unemployment (Bassanini and Duval, 2006).

35. No robust results emerge for unemployment benefits and the tax wedge. This could signal that they do not have an important effect on the overall income distributions, perhaps because different channels offset each other. On the other hand, it could suggest that more complex specifications, supported by more comprehensive datasets on income distributions as well as on factors or policies affecting them, are required before drawing firmer conclusions on their relationship with income inequality.

\section{Poverty incidence and persistence during the $1990 \mathrm{~s}$}

36. This section reviews the dynamic aspects of poverty on the basis of longitudinal data for the EU-15 and the United States since the first half of the 1990s. ${ }^{25}$ Risk of entry into poverty, duration of poverty spells and income mobility of the poor provide important information about the nature of poverty. Arguably, high poverty rates are more serious when they reflect a large number of people being poor over a protracted period than if they mirror a transitory state with most poor people rapidly moving above the poverty threshold. The last part of this section also explores econometrically the link between labour market institutions/policies and relative poverty.

\subsection{Poverty variables}

37. Throughout this section, individuals are defined to be in relative poverty if their annual disposable income falls below the relative poverty threshold of $50 \%$ of the median individual equivalent annual disposable income. Given this threshold, a number of indicators of relative poverty incidence and persistence are calculated for each country.

38. As in previous sections, the annual relative poverty rate is defined as the share of individuals over the total population with annual income below the poverty threshold. The annual poverty entry rate in year $t$ is defined as the share of the individuals not poor in year $t-1$ whose income falls below the poverty threshold in year $t$. The annual poverty exit rate in year $t$ is the share of individuals poor in year $t-1$ whose income rises above the poverty threshold in year t. These indicators can be interpreted as conditional probabilities of entering and exiting relative poverty in a given year. ${ }^{26}$ Columns 1-3 in Table 15 report the averages of the above annual measures during the time period considered in the analysis.

25. The longitudinal dataset used for the EU-15 countries is the European Community Household Panel (ECHP) while the one used for the US is the Cross National Equivalent File (CNEF). See Annex 1 for details.

26. Because the 1998 and 2000 waves are not available for the United States, for the 1999 and 2001 US waves the reference period to calculate entry into and exit from poverty is two years rather than one year. 


\section{[Table 15. Indicators of poverty risk]}

\section{[Table 16. Cross-correlations of poverty measures]}

39. The at-least-once-poor rate is the share of individuals whose income falls below the poverty threshold for at least one year during the time period considered in the analysis and can be interpreted as an indicator of overall poverty incidence (column 4 in Table 15). The chronic poverty rate is defined as the share of the total population or of the at-least-once poor whose average income over the time period considered in the analysis falls below the corresponding average poverty threshold (columns 7 and 8 in Table 15). The chronic-poverty-with-exits rate measures the share of chronic poor that report at least one year of income above the poverty threshold during the time period considered in the analysis (column 9 in Table 15). In contrast, the always-poor rate is calculated as the share of the total population or of the chronic poor whose income falls below the poverty threshold during all years of the time period considered in the analysis (columns 10 and 11 in Table 15).

40. Finally, some indicators for the duration of poverty spells are computed. The average time spent in poverty by individuals at-least-once-poor is defined as the number of years in poverty for the individuals at-least-once-poor as a share of the total number of years considered in the analysis (column 5 in Table 15). The average duration of uncensored poverty spells is calculated as the average number of years of those poverty spells for which it was possible to observe both the starting and ending dates during the time period considered in the analysis (column 6 in Table 15). ${ }^{27}$ Further indicators of duration are calculated in Annex $4 .^{28}$

\subsection{Poverty incidence and dynamics: cross-country differences}

41. The average poverty rate has been higher in the US than in the EU/ECHP ${ }^{29}$ countries on average during the second half of the 1990s (Table 15). Nonetheless, the European average masks considerable variation across countries. Nordic European countries, the Netherlands and Luxembourg display relatively low poverty rates, while Southern European countries, the United Kingdom and Ireland have comparatively high poverty rates (column 1 of Table 15). The remaining EU-15 countries in the study (Germany, Austria, Belgium and France) stand in an intermediate position. The cross-country pattern of the other indicators of poverty incidence and poverty persistence is very similar to the average poverty rate. Indeed, all indicators considered in this section show a strong correlation with the average poverty rate (Table 16).

27. The longitudinal dataset used for the United States becomes biannual starting from the 1997 wave. Therefore, a number of assumptions had to be made for spells ending in the 1999 or 2001 waves and for those starting in the 1999 wave. For those ending in 1999, it was assumed that they ended at the mid-point between 1998 and 1999. So for example, for a spell starting in 1995 and ending in 1999 duration of 3.5 years was assumed. For the spells ending in 2001, it was assumed that they ended at the mid-point between 2000 and 2001. Finally, for the spells starting in 1999, it was assumed that they started at the mid-point between 1998 and 1999. Therefore, for those spells starting in 1999 and ending in 2001 duration of 2 years was assumed. This calculation method might slightly overestimate actual average spell duration for the United States as long as the distribution of spell durations is right-skewed.

28. A sensitivity analysis of the above poverty measures to alternative sampling assumptions (e.g. a shorter time period) has been carried out and is available upon demand.

29. Here and in the remainder of the paper, the term EU/ECHP will denote the countries participating to all ECHP waves, i.e. EU-15 excluding Austria, Finland, Luxembourg and Sweden. Notice that the lower number of waves for these latter countries could affect the comparability of their indicators with those of the other countries. 
42. High poverty rates are generally associated with high entry rates into poverty (column 2 in Table 15). Thus, entry rates in high-poverty countries tend to be more than twice as high as in low-poverty countries. The link between exit rates and poverty incidence is more tenuous (column 3 in Table 15). For example, high poverty rates in Spain are accompanied by relatively high exit rates, and low poverty rates in Finland go hand in hand with low exit rates. However, the average time spent in poverty tends to be much longer in high-poverty than in low-poverty countries (columns 5-6 in Table 15). ${ }^{30}$

43. There is a less clear association between the proportion of the "at-least-once" poor that are in "chronic" poverty, i.e. with incomes below poverty on average during the period considered (column 8 in Table 15) and overall poverty incidence. For example, the share of the chronic poor is about $20 \%$ in the United Kingdom, lower than the EU/ECHP average, despite its poverty incidence being higher. It remains, though, that the countries with the lowest and highest poverty rates in the sample also have the lowest and highest chronic poverty rates.

44. The link is also tenuous between the overall poverty incidence and the two key components of chronic poverty: permanent poverty (defined as the "always-poor" in columns 10-11 in Table 15) and chronic poverty with exits (column 9 in Table 15). The share of the population with incomes permanently below the poverty line ranges from practically zero in some countries with low poverty incidence, such as Denmark and the Netherlands, to three per cent in the United States that also has the highest poverty rate (column 10 in Table 15). But a low share is found in high-poverty countries like Spain or Italy, sometimes below that in EU-15 countries with much lower average poverty rates. Correspondingly, these two countries have among the highest share of the chronic poor that sometimes exit poverty, only slightly lower than that of low-poverty countries like Denmark and the Netherlands (column 9 in Table 15).

45. An important issue related to poverty persistence is the extent to which individuals below the income poverty line in a given year are able to permanently move up the income scale in subsequent years. This can be assessed by looking at the average income in the 1995-2001 waves of those individuals who were poor in the 1994 wave but exited poverty one year later (Table 17). ${ }^{31}$

46. Two messages stand out from the analysis of income mobility. First, in countries with high "static" poverty rates, exiting poverty permanently is less likely than on average, as shown by the relatively high share of individuals exiting poverty in the 1995 wave but still experiencing "chronic" poverty in the 1995-2001 waves (column 1 of Table 17). ${ }^{32}$ Nevertheless, upward mobility of the poor seems less related to the degree of "static" poverty (column 3 of Table 17). In fact, both low-poverty countries (France, Denmark or the Netherlands) and high-poverty ones (Ireland, the United States, the United Kingdom or Spain) post a relatively high share of previously poor individuals with average income above the median during the 1995-2001 waves.

[Table 17. Income-mobility indicators for 1994-wave poor exiting poverty in 1995 wave]

30. Annex 4 discusses alternative ways to measure the duration of poverty spells.

31. Because of lack of waves, later dates for the starting wave had to be chosen for Austria, Finland and Luxembourg. See footnotes to Table 17 for details.

32. Ireland is an exception as its share is similar to the ones of low-poverty countries. Finland represents the opposite case because its share is high despite posting low "static" poverty rates. 


\subsection{Individual and household characteristics and poverty risk}

47. This sub-section examines to what extent individual and household characteristics have affected poverty risk, in terms of both incidence and persistence, during the 1990s. Table 18 shows the ratios of the at-least-once-poor rate and of the chronic poverty rate for groups with specific characteristics divided by the corresponding rates for the whole population. A value of these ratios greater (lower) than one for a certain group indicates that the poverty likelihood is higher (lower) for this group than for the whole population.

\section{[Table 18. Relative risk of poverty]}

48. The risk profile of poverty incidence and persistence by age group is very similar in Europe and the United States (Figure 4). Children face a higher risk of poverty incidence and, especially, persistence than the whole population. The relative risk of poverty incidence increases for the 15-24 age group but that of poverty persistence decreases, probably because many young people start earning an income. Nevertheless, the risk of poverty persistence for the 15-24 year olds remains higher than for the whole population in the United States. As youth have a higher job turnover than adults, this could account for their relatively higher risk of poverty in both the EU and the United States compared to the adults.

\section{[Figure 4. Relative poverty risk profile by age group]}

49. The relative risk of poverty incidence and persistence decreases substantially for the 25-54 age groups. The poverty risk starts rising again after age 55 in Europe on average, although remaining broadly at the level of the whole population. In contrast, it keeps decreasing until age 65 in the United States where barriers to continued work for older persons are lower (OECD, 2005a). Retired people in the United States face, nevertheless, a higher relative poverty risk than in the EU probably because of lower pension floors (relative to the poverty line) compared with the EU on average (Förster and Mira d'Ercole, 2005). For the EU countries, relative poverty risk for this age group could be even over-estimated as implicit rent is not included among the income variables in the ECHP datasets. ${ }^{33}$

50. Some country exceptions stand out in Europe (Table 18). In Finland and Denmark, poverty incidence and persistence risk is lower for children than for the whole population, probably reflecting the role of Northern European countries' policies targeted to this age group (Council of the European Union, 2004, and OECD, 2005a). The relative risk of poverty incidence and persistence keeps falling rather than starts rising in the United Kingdom after age 55 and before the standard age of retirement, probably reflecting a higher employment rate at older ages. Finally, in the Netherlands older persons (over 65) face a lower risk of poverty incidence and persistence than the whole population, contrary to the other European countries.

51. In most countries, the risk of poverty incidence and persistence is much higher for singles - especially with children, more so in the United States than in the EU countries on average - than for couples, probably because single parents are more likely to have no earned income or hold a low-pay or part-time job (OECD, 2005b). Poverty risk for single females is higher than for males. High poverty risk

33. This could be particularly true for Southern European countries where the share of older people living in their own house is higher than in the other EU countries (Council of the European Union, 2004). Therefore, the differences in poverty rates among EU countries shown in Table 15 could partly be reduced if imputed rents were included in the income definition. Results of relative risk of poverty among older age groups could also be affected by the choice of the scale used to calculate equivalent income (Burkhauser et al., 1996 and Annex 1). This is because most older-age individuals live in households with relatively few members. Thus, equivalence scales assuming larger (smaller) economies of scale would tend to push up (push down) old-age poverty incidence compared to that of the whole population. 
for singles with children might explain at least partly why in many countries individuals under the age of 14 face a relatively high likelihood of poverty incidence. This has raised concerns in many countries, prompting the implementation of policies favouring single families with children (see OECD, 2005a). ${ }^{34}$

52. Both educational achievement and employment status have a strong influence on the likelihood of poverty incidence and persistence. Adult individuals with less than upper-secondary education face a much higher poverty risk than the rest of the population as the likelihood to hold a low-pay job is higher (OECD, 2005b). The chronic poverty rate for the low-skilled is almost $50 \%$ higher than for the whole population on average in the EU countries and more than double in the United States. ${ }^{35}$

53. Individuals from households where no working-age member secures income from work have a significantly higher risk of poverty incidence ${ }^{36}$ and, especially, persistence (Figure 5). The presence of occasional or part-time workers is in general not enough to reduce significantly the relative risk of poverty incidence and persistence. By contrast, in a majority of countries, individuals in households with one full-time worker face similar probabilities of poverty incidence as the whole population and a lower risk of poverty persistence. Moreover, the presence of a second earner in the family reduces the likelihood of falling into poverty below that of the whole population in all countries. ${ }^{37}$ These results confirm the findings in OECD (2001), Council of the European Union (2004) and Valletta (2004) that show that work status is an important determinant of poverty in OECD countries.

[Figure 5. Relative poverty risk by working status, 1994-2001]

\subsection{Labour market performance and poverty risk}

54. Good labour market performance is in general associated with low poverty. Table 19 shows simple bivariate correlations of the poverty rate, the poverty entry rate and the poverty exit rate with selected labour market variables during the 1993-2000 period. Higher participation and employment rates are associated with lower poverty rates - in line with the results of Table 9 where a longer time period is used -, lower probability of entry into poverty and higher probability of exit. Unemployment - especially long-term unemployment - is positively correlated with a higher risk of entering into poverty and with higher poverty rates.

\section{[Table 19. Correlations of poverty measures with labour market aggregates]}

55. Overall, the sub-group correlations for women are stronger than for men, confirming the central role of women's earnings in reducing poverty risks. Indeed, the correlations are in general statistically

34. For example, the British government has set the target to halve child poverty by 2010 and to eradicate it by 2020. See the 2005 OECD Economic Survey of the United Kingdom.

35. Valletta (2004) finds that in the US, poverty persistence and transitions are closely related to educational attainment and earnings variability, especially for low-income individuals.

36. See also OECD (2005a) for the influence of employment status on poverty rates.

37. The only exception is Luxembourg where the risk of poverty incidence seems higher for two-worker families than for the whole population. However, this result could be due to small-sample errors. Moreover, for some EU countries relative poverty risk for individuals living in households with two fulltime workers is higher than for individuals living in households with one full-time worker and one parttime worker. But this result could be also due to small-sample errors. Another possible explanation could be that second earners in households where the first earner has a high-paid job "can afford" to work only part-time rather than full-time and the household income would still exceed that of households with two lower-paid full-time workers. 
insignificant for men and highly significant for women. These results are consistent with the evidence in OECD (2005a) and Förster and Mira d'Ercole (2005), which shows that lower relative poverty among children is associated with higher employment rate among mothers in OECD countries, especially to the extent that higher mothers' employment reduces the number of workless households.

56. Although statistically significant, the size of the above correlations suggests that other forces besides labour force status could be at work in explaining the pattern of poverty rates and poverty dynamics across countries and over time. Indeed, OECD (2005a) shows that cross-country correlations of employment rates with poverty rates calculated at the level of market income are much higher than those with poverty rates calculated at the level of disposable income. Therefore, the availability and generosity of social programmes could be an important factor.

57. To further explore the link between labour market institutions/policies and poverty incidence, ${ }^{38}$ multivariate regression analysis has been carried out. The dependent variable in the regressions presented in this section is the relative poverty rate with poverty threshold at $50 \%$ of median income in each country. The specification and estimation strategy is similar to the one carried out for the inequality indicators in Section 2.

58. As for the inequality indicators, assuming no country or year heterogeneity, the coefficients of all the policies/institutions, alongside average years of education, have a negative sign (Table 20, column 1). In contrast, the coefficient of the capital/labour ratio shows a positive sign. However, F-tests (available on request) show that country- and year-fixed effects are jointly significant and also that each set of effects is significant given the other. Therefore, although results using other specifications/estimation methods are shown in Table 20, the baseline model is the one with country- and year-fixed effects (column 2).

59. With this specification, only the coefficients of union density and the tax wedge continue displaying a significantly negative sign while the impact of the average years of education turns significantly positive (Table 20, column 2). These results are confirmed in the model with country-random effects (column 3 ). The negative impact of the tax wedge on poverty could be explained by the fact that tax revenues are used to finance social programmes. Indeed, in column 4 when social expenditures are included (and the tax wedge is ecluded) their impact is significantly negative. In the regression with ALMP spending, the signs of coefficients hold although they are not statistically significant anymore (column 5). However, this could be mostly due to missing observations because of limited data availability of ALMP spending. ${ }^{39}$ Finally, the results of the baseline regression are confirmed when using the sample with 5-year averages (column 6).

\section{[Table 20. Regression of relative poverty against labour market institutions/policies]}

60. The bargaining power of the unions seems, thus, to have a role in limiting relative poverty. Furthermore, the tax wedge has a negative impact on relative poverty, probably because the corresponding revenues are mainly used to finance social programmes. The positive effect of average years of education is harder to explain as higher education is in general thought to reduce the individual probability of becoming poor as long as returns to education are positive. However, the measure of poverty used in this paper is a relative one. Therefore, the impact of average years of education will depend on the income

38. This is a theme that has been neglected so far in the macro-econometric literature.

39. An additional regression (available on request) was run using the method proposed by Griliches (1986) to obtain consistent estimates of the coefficients of the variables (other than ALMP spending) by using the whole estimation sample despite missing data on ALMP. These estimates show that the coefficient of union density is significantly negative while the one by average years of education significantly positive. The coefficient of the tax wedge is negative but not significant at conventional confidence levels. 
groups that have mostly benefited from this increase. For example, if an increase in average years of education stem mostly from higher educational attainments by individuals in the median and top income groups, this would likely lead to an increase in relative poverty rates. This is an issue that would deserve further research. 


\section{BIBLIOGRAPHY}

Alderson, A. S., and F. Nielsen (2002), "Globalisation and the Great U-Turn: Income Inequality Trends in 16 OECD Countries”, American Journal of Sociology, Vol. 107, pp.1244-1299.

Atkinson, A.B. (2004), “The Luxembourg Income Study (LIS): Past, Present and Future”, Socio-Economic Review, Vol. 2, pp.165-190.

Atkinson, A.B. and A. Brandolini (2001), "Promise and Pitfalls in the Use of "Secondary" Data-Sets: Income Inequality in OECD Countries", Journal of Economic Literature, Vol. 34, pp.771-799.

Atkinson, A.B. and A. Brandolini (2004), "The Panel-of-countries Approach to Explaining Income Inequality: An Interdisciplinary Research Agenda", mimeo.

Atkinson, A.B., A. Brandolini, P. van der Laan and T. Smeeding (2000), "Producing Time Series Data for Income Distribution: Sources, Methods and Techniques", prepared for the Canberra Group Meeting, Luxembourg, May 15-17, 2000.

Bassanini A. and R. Duval (2006), "Employment Patterns in OECD Countries: Reassessing the Role of Policies and Institutions", OECD Economics Department Working Paper, No. 486, Paris.

Blanchflower, D. G. and M. J. Slaughter (1999), "The Causes and Consequences of Changing Income Inequality", in Fishlow A. and K. Parker (eds.), Growing Apart: The Causes and Consequences of Global Wage Inequality, Council on Foreign Relation Press, Washington D.C.

Checchi, D. and C. Garcia-Penalosa (2005), "Labour Market Institutions and the Personal Distribution of Income in the OECD”, IZA Discussion Paper, No. 1681.

Citro, C.F. and R.T. Michael (eds.) (1995), Measuring Poverty. A New Approach, National Academic Press, Washington D.C.

Council of the European Union (2004), Joint Report by the Commission and the Council on Social Inclusion, Council of the European Union, Brussels.

Deaton, A. (2003), "How to Monitor Poverty for the Millennium Development Goal", Research Program in Development Studies, Princeton University.

de Groot, H.L.F, P.J.G Tang and R. Nahuis (2004), "Is the American Model Miss World? Choosing Between the Anglo-Saxon Model and a European-Style Alternative", Tjalling C. Koopmans Research Institute Discussion Paper Series, 04-26.

Förster, M and M. Mira d'Ercole (2005), "Income Distribution and Poverty in OECD Countries in the Second Half of the 1990s", OECD Social, Employment and Migration Papers, No. 22.

Foster, J.E. (1998), “Absolute versus Relative Poverty”, American Economic Review, Vol. 88, No. 2, Papers and Proceedings.

Galli, R. and R. van der Hoeven (2001), "Is Inflation Bad for Income Inequality: The Importance of the Initial rate of Inflation", ILO Employment Paper, 2001/29. 
Griliches, Z. (1986), “Economic Data Issues”, in Z. Griliches and M.D. Intriligator: Handbook of Econometric, Volume III, Elsevier, pp. 1466-1514.

Gustafsson, B. and M. Johansson (1999), "In Search of Smoking Guns: What Makes Income Inequality Vary over Time in Different Countries?", American Sociological Review, Vol. 64, pp.585-605.

Hausman, J.A. (1978), "Specification Tests in Econometrics”, Econometrica, Vol. 46, pp.12511271.

Koeniger, W., M. Leonardi and L. Nunziata (2004), "Labour Market Institutions and Wage Inequality", IZA Discussion Paper, No. 1291.

Madden, D. (2000), "Relative or Absolute Poverty Lines: A New Approach", Review of Income and Wealth, Vol. 46, Number 2.

Mahler, V.A. (2004), "Economic Globalisation, Domestic Politics and Income Inequality in the Developed Countries: A Cross-National Analysis", Comparative Political Studies, Vol.37, pp.1025-1053.

Moulton, B.R (1987), "Diagnostics for Group Effects in Regression Analysis", Journal of Business and Economic Statistics, Vol. 5, No.2.

OECD (1994), The OECD Jobs Study: Implementing the Strategy, Paris.

OECD (1997), Implementing the OECD Jobs Strategy: Lessons from Member Countries' Experience, Paris.

OECD (2001), "When Money is Tight: Poverty Dynamics in OECD Countries", OECD Employment Outlook 2001, Paris.

OECD (2005a), Extending Opportunities. How Active Social Policy Can Benefit Us All, Paris.

OECD (2005b), "Increasing Financial Incentives to Work: The Role of Employment-Conditional Benefits", OECD Employment Outlook, 2005, Paris.

OECD (2006), "Fundamental Reform of Personal Income Tax”, OECD Tax Policy Studies, No. 13.

Reddy, S. G. and T.W. Pogge (2005), "How Not to Count the Poor", Columbia University, mimeo.

Smeeding, T.M., D.K. Jesuit and P. Alkemade (2002), "The LIS/LES Project Databank: Introduction and Overview", Schmollers Jahrbuch, 122.

Smeeding, T.M., L. Rainwater and G. Burtless (2000), "United States Poverty in a Cross-National Context”, Luxembourg Income Study Working Paper, No. 244.

Valletta, R. (2004), "The Ins and Outs of Poverty in Advanced Economies: Poverty Dynamics in Canada, Germany, Great Britain and the United States", Federal Reserve Bank of San Francisco Working papers in Applied Economic Theory, 2004-18. 
ECO/WKP(2006)28

\section{TABLES AND FIGURES}


Table 1. Cross-correlations of inequality and poverty measures

1970-2001

\begin{tabular}{|c|c|c|c|c|}
\hline & Gini Index - Overall & 9th/1st decile ratio & Median/1st decile ratio & Poverty rate \\
\hline Gini Index - Overall & 1.00 & & & \\
\hline 9th/1st decile ratio & $0.96^{* * *}$ & 1.00 & & \\
\hline Median/1st decile ratio & $0.88^{* \star *}$ & $0.96^{* * *}$ & 1.00 & \\
\hline Poverty rate & $0.90^{* * *}$ & $0.96^{* * *}$ & $0.97^{\star * \star}$ & 1.00 \\
\hline
\end{tabular}

*** significant at $1 \%$

Sources: Förster and Mira d'Ercole (2005), Luxembourg Income Study (LIS) data set, European Community

Household Panel (ECHP) data set and Cross National Equivalent Files (CNEF) data set. 
Table 2. Trends of unemployment and overall income inequality

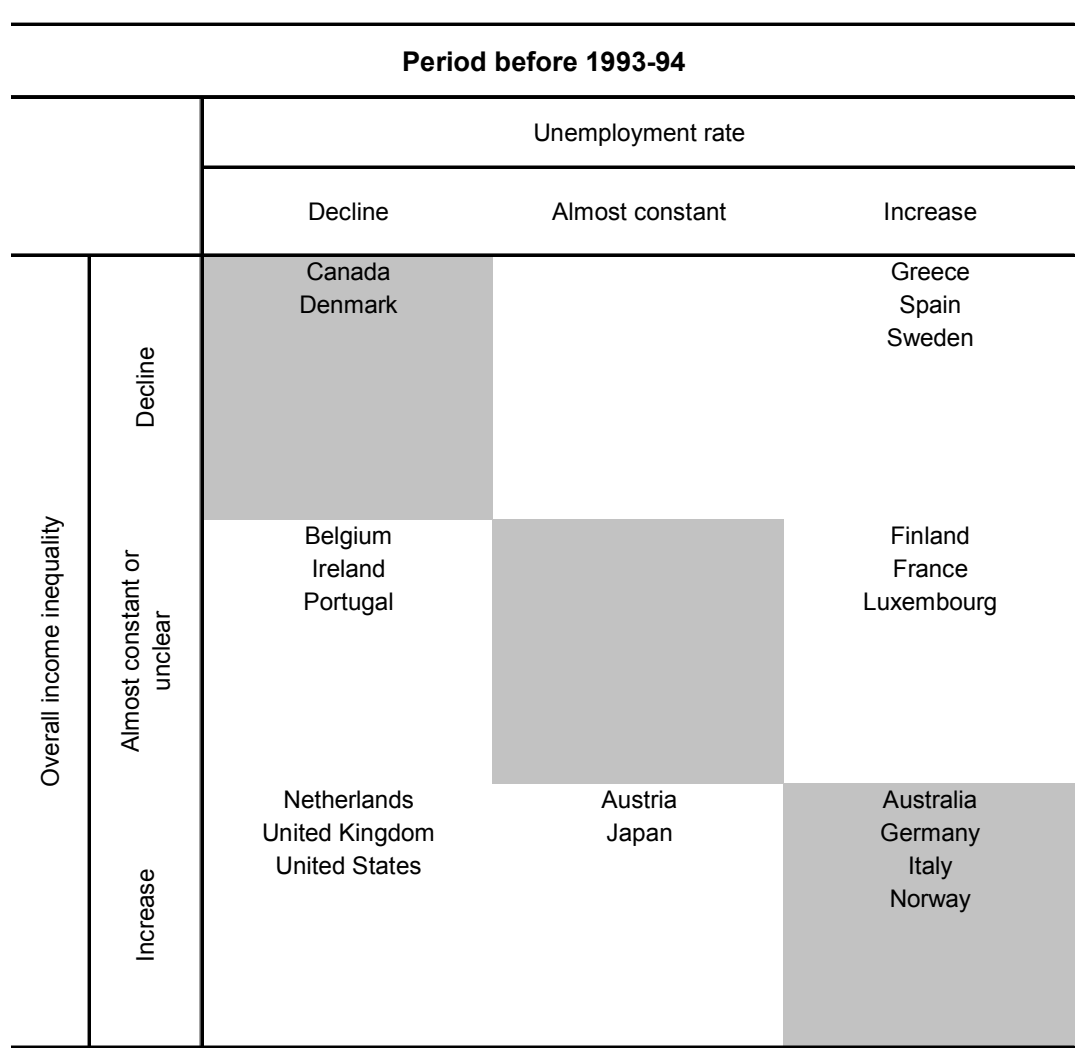

\begin{tabular}{|c|c|c|c|c|}
\hline \multicolumn{5}{|c|}{ Period after 1993-94 } \\
\hline & & & Unemployment rate & \\
\hline & & Decline & Almost constant & Increase \\
\hline \multirow{3}{*}{ 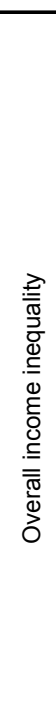 } & 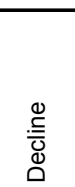 & $\begin{array}{l}\text { France } \\
\text { Italy } \\
\text { Netherlands } \\
\text { Spain }\end{array}$ & Portugal & $\begin{array}{c}\text { Austria } \\
\text { Germany }\end{array}$ \\
\hline & 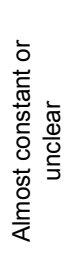 & $\begin{array}{l}\text { Belgium } \\
\text { Ireland } \\
\text { Norway } \\
\text { United States }\end{array}$ & & Greece \\
\hline & 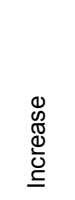 & $\begin{array}{l}\text { Canada } \\
\text { Denmark } \\
\text { Finland } \\
\text { Sweden } \\
\text { United Kingdom }\end{array}$ & & $\begin{array}{c}\text { Japan } \\
\text { Czech Republic } \\
\text { Luxembourg }\end{array}$ \\
\hline
\end{tabular}

Note: For the unemployment rate, "almost constant" refers to changes of 0.5 percentage points or less. The assessment of changes in overall income inequality is based on 2 different indicators

(Gini coefficient, ratio of average income of 9th to 1st decile) and 4 different data sets: Förster and Mira d'Ercole (2005), Luxembourg Income Study (LIS) data set, European Community

Household Panel (ECHP) data set and Cross National Equivalent Files (CNEF) data set. See Annex 1 for details on the methodology and Annex 2 for the detailed results. 
ECO/WKP(2006)28

Table 3. Trends of unemployment and relative poverty

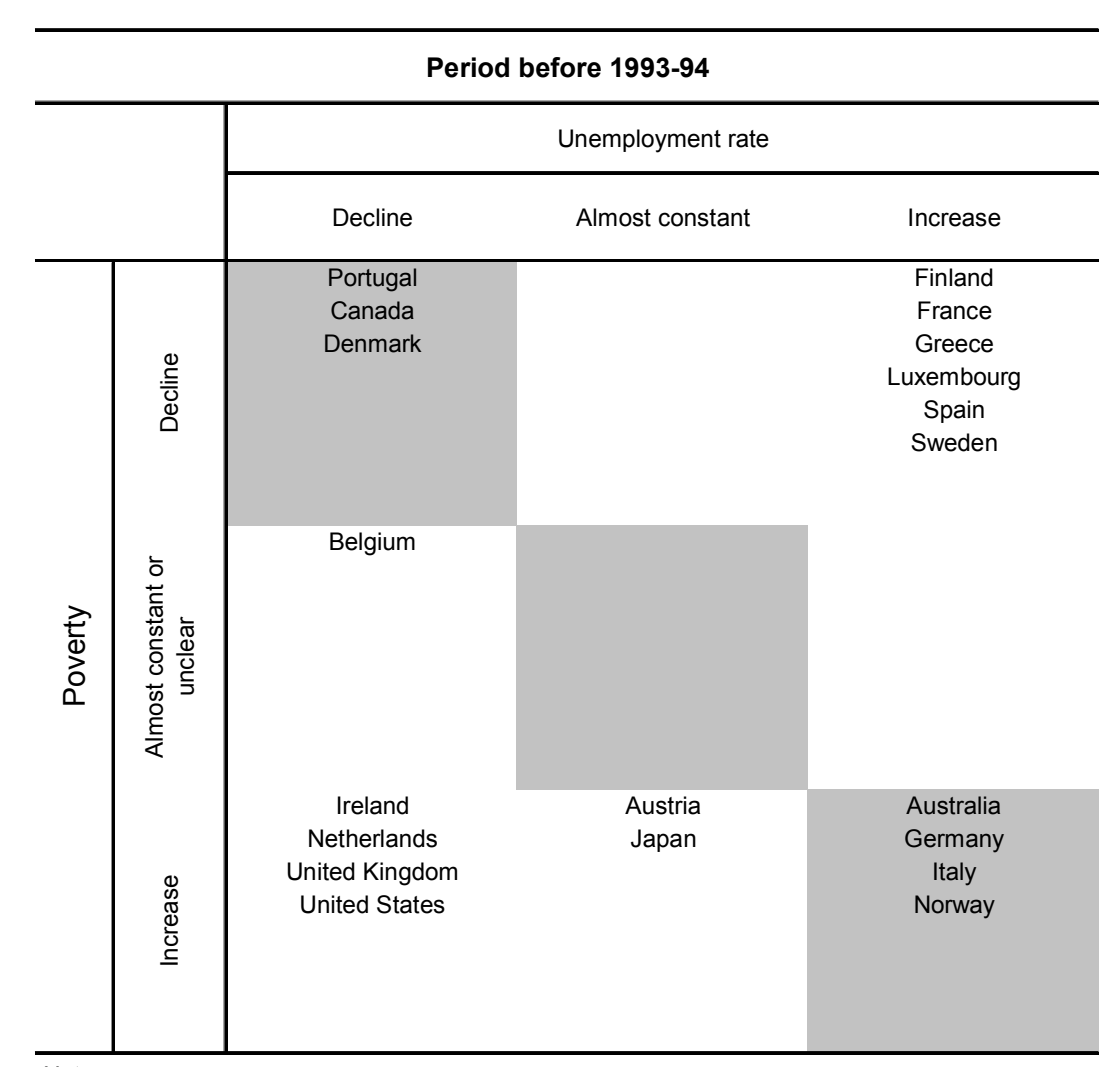

\begin{tabular}{|c|c|c|c|c|}
\hline \multicolumn{5}{|c|}{ Period after 1993-94 } \\
\hline & & & Unemployment rat & \\
\hline & & Decline & Almost constant & Increase \\
\hline \multirow{3}{*}{ 密 } & 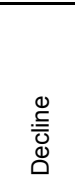 & $\begin{array}{c}\text { Italy } \\
\text { Netherlands } \\
\text { Norway }\end{array}$ & Portugal & $\begin{array}{l}\text { Austria } \\
\text { Greece }\end{array}$ \\
\hline & 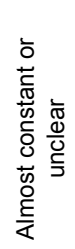 & $\begin{array}{c}\text { Belgium } \\
\text { France } \\
\text { United Kingdom } \\
\text { United States }\end{array}$ & & Germany \\
\hline & 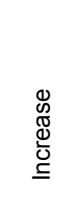 & $\begin{array}{l}\text { Canada } \\
\text { Denmark } \\
\text { Ireland } \\
\text { Finland } \\
\text { Spain } \\
\text { Sweden }\end{array}$ & & $\begin{array}{l}\text { Czech Republic } \\
\text { Japan } \\
\text { Luxembourg }\end{array}$ \\
\hline
\end{tabular}
(proportion of individual with income below $50 \%$ and $60 \%$ of the median income, respectively) and 4 different data sets: Förster and Mira d'Ercole (2005), Luxembourg Income Study

(LIS) data set, European Community Household Panel (ECHP) data set and Cross National Equivalent Files (CNEF) data set. See Annex 1 for details on the methodology and

Annex 2 for the detailed results. 


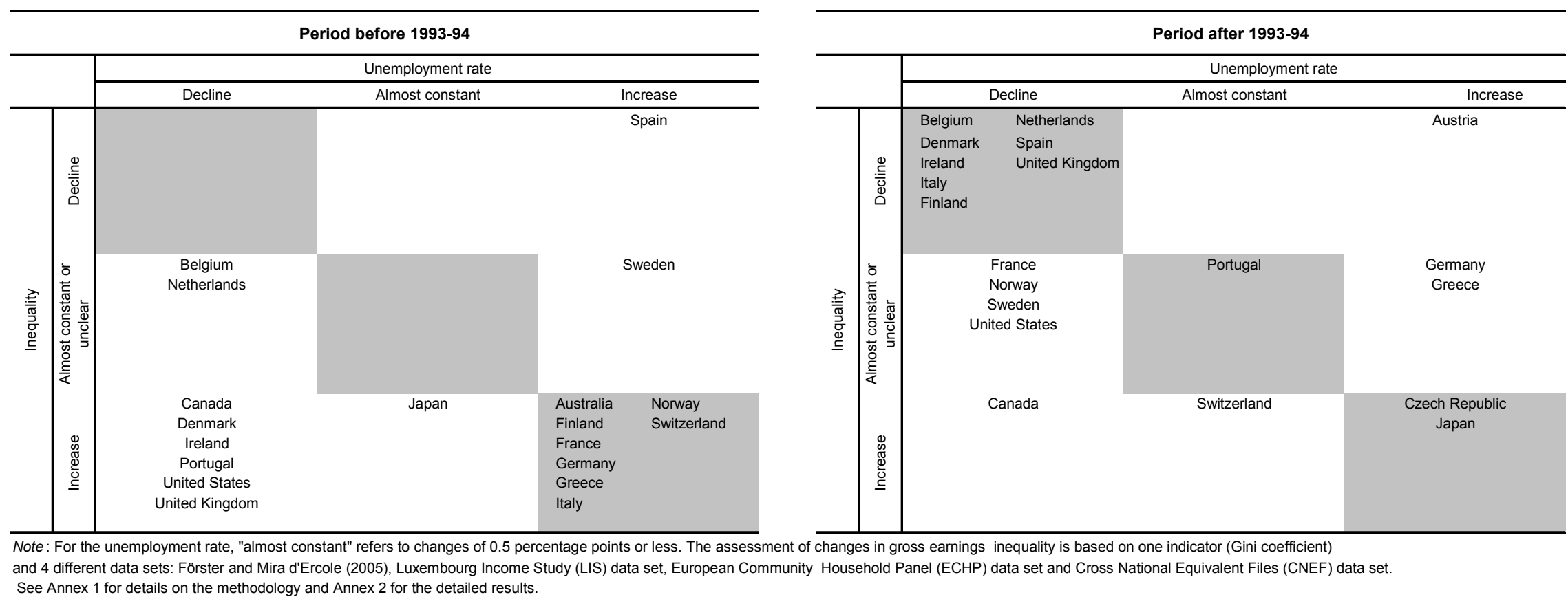


ECO/WKP(2006)28

Table 5. Trends of unemployment and gross earning inequality in three bottom earnings deciles of the population

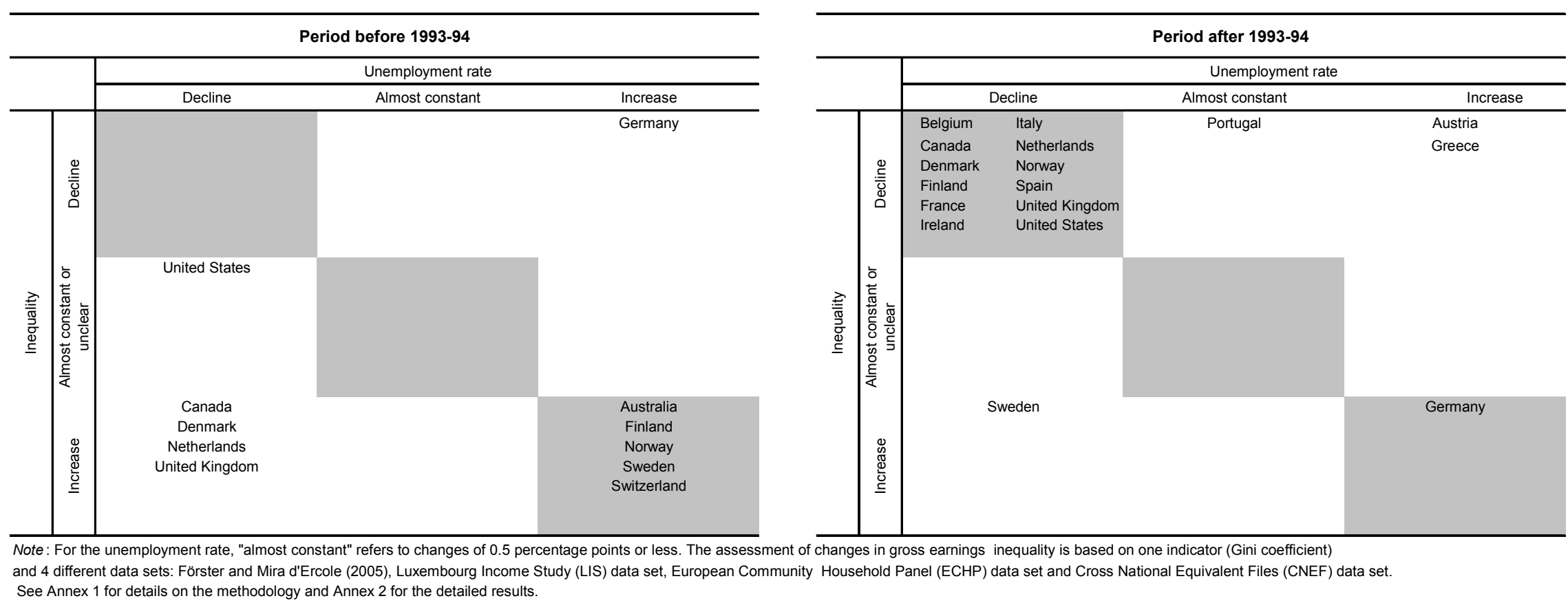


Table 6. Trends of unemployment and gross earnings inequality for the employed population

\begin{tabular}{l}
\hline \multicolumn{2}{c|}{ Period before 1993-94 } \\
\hline
\end{tabular}


Table 7. Trends of unemployment and transfers' redistributive impact

\begin{tabular}{|c|c|c|c|c|c|c|c|c|c|c|}
\hline \multicolumn{5}{|c|}{ Period before 1993-94 } & & & \multicolumn{4}{|c|}{ Period after 1993-94 } \\
\hline & & \multicolumn{3}{|c|}{ Unemployment rate } & & & \multicolumn{4}{|c|}{ Unemployment rate } \\
\hline & & Decline & Almost constant & Increase & & & & cline & Almost constant & Increase \\
\hline \multirow{3}{*}{ 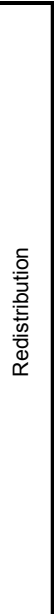 } & \begin{tabular}{|l|}
$\stackrel{\mathscr{D}}{\bar{c}}$ \\
$\stackrel{0}{0}$ \\
$\stackrel{0}{0}$
\end{tabular} & United Kingdom & & & \multirow{3}{*}{ 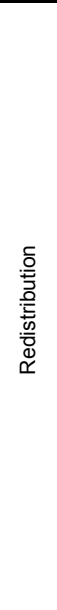 } & $\begin{array}{l}\frac{\mathscr{\Xi}}{\overline{\underline{E}}} \\
\stackrel{\Phi}{\Delta}\end{array}$ & $\begin{array}{l}\text { Belgium } \\
\text { Canada } \\
\text { Denmark } \\
\text { Finland } \\
\text { Ireland }\end{array}$ & $\begin{array}{l}\text { Netherlands } \\
\text { Norway } \\
\text { Spain } \\
\text { United Kingdom } \\
\text { United States }\end{array}$ & & Austria \\
\hline & 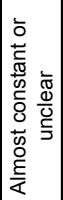 & $\begin{array}{l}\text { Netherlands } \\
\text { Portugal }\end{array}$ & & $\begin{array}{l}\text { France } \\
\text { Italy } \\
\text { Switzerland }\end{array}$ & & 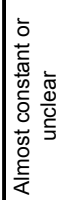 & & $\begin{array}{l}\text { ance } \\
\text { eden }\end{array}$ & Portugal & Greece \\
\hline & 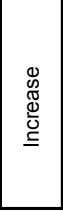 & $\begin{array}{l}\text { Belgium } \\
\text { Canada } \\
\text { Denmark } \\
\text { Ireland } \\
\text { United States }\end{array}$ & Japan & $\begin{array}{l}\text { Australia } \\
\text { Finland } \\
\text { Germany } \\
\text { Greece } \\
\text { Norway } \\
\text { Spain } \\
\text { Sweden } \\
\end{array}$ & & 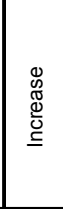 & & aly & Switzerland & $\begin{array}{l}\text { Czech Republic } \\
\text { Germany } \\
\text { Japan }\end{array}$ \\
\hline
\end{tabular}

Note: For the unemployment rate, "almost constant" refers to changes of 0.5 percentage points or less. The assessment of changes in transfers' redistributive impact is based on 3 different methods of inequality Panel (ECHP) data set and Cross National Equivalent Files (CNEF) data set. See Annex 1 for details on the methodology and Annex 2 for the detailed results. 
Table 9. Correlations of inequality and poverty measures with labour market aggregates ${ }^{a}$

\begin{tabular}{lllll} 
& \multicolumn{2}{c}{$\mathbf{1 9 7 0 - 2 0 0 1}$} & & \\
\hline & Gini Index & 9th/1st decile ratio & $\begin{array}{c}\text { Median/1st decile } \\
\text { ratio }\end{array}$ & Poverty rate \\
\cline { 2 - 5 } Participation rate - total & $-0.27^{* * *}$ & $-0.16^{* *}$ & -0.08 & $-0.15^{* *}$ \\
Participation rate - male & -0.02 & 0.12 & $0.19^{* * *}$ & 0.11 \\
Participation rate - female & $-0.30^{* * *}$ & $-0.23^{* * *}$ & $-0.16^{*}$ & $-0.22^{* * *}$ \\
Employment rate - total & $-0.29^{* * *}$ & $-0.18^{* *}$ & -0.11 & $-0.18^{* *}$ \\
Employment rate - male & $-0.12^{* *}$ & 0.02 & 0.09 & 0.00 \\
Employment rate - female & $-0.32^{* * *}$ & $-0.23^{* * *}$ & $-0.16^{* *}$ & $-0.22^{* * *}$ \\
Unemployment rate - total & $0.24^{* * *}$ & $0.16^{* *}$ & 0.12 & $0.18^{* *}$ \\
Unemployment rate - male & $0.21^{* * *}$ & 0.15 & $0.12^{*}$ & $0.17^{* *}$ \\
Unemployment rate - female & $0.24^{* * *}$ & $0.16^{* *}$ & 0.11 & $0.17^{* *}$ \\
Long-term unemployment rate - total & $0.19^{* *}$ & 0.07 & -0.02 & 0.07 \\
Long-term unemployment rate - male & $0.18^{* *}$ & 0.06 & -0.03 & 0.06 \\
Long-term unemployment rate - female & $0.19^{* *}$ & 0.08 & 0.00 & 0.08 \\
\hline
\end{tabular}

* significant at $10 \%$; ** significant at $5 \%$; *** significant at $1 \%$

a) Both inequality and labour market variables have been adjusted for the cycle. Labour market aggregates refer to working age population (15-64 age group).

Sources: Förster and Mira d'Ercole (2005), Luxembourg Income Study (LIS) data set, European Community Household Panel (ECHP) data set and Cross National Equivalent Files (CNEF) data set, OECD Employment Outlook. 
ECO/WKP(2006)28

Table 10. Cross-country time-series reduced-form estimates of income inequality models

\begin{tabular}{|c|c|c|c|c|c|c|}
\hline Study & $\begin{array}{c}\text { Sample, estimation period and number of } \\
\text { observations }\end{array}$ & Dependent variable & Income definition & Regressors - institutions and policies ${ }^{a}$ & Estimation method & Notes \\
\hline Alderson and Nielsen (2002) & $\begin{array}{l}16 \text { OECD countries, 1967-1992, } 187 \\
\text { observations }\end{array}$ & Gini index & Income definitions change across countries & $\begin{array}{l}\text { union density }[-] \text {-] index of generosity of } \\
\text { sickness, maternity and unemployment benefit } \\
\text { system [--]; wage coordination }[--1]\end{array}$ & $\begin{array}{l}\text { Generalised linear model with robust standard } \\
\text { terrors (asymptotically equivalent to random- } \\
\text { effect LSS with robust standard elrors) }\end{array}$ & \\
\hline Checchi and Garcia-Penalosa (2005) & $\begin{array}{l}\text { Full sample: } 16 \text { OECD countries, } 1970-1996, \\
211 \text { observations; Restricted sample: } 6 \text { OECD } \\
\text { countries, } 1907-1996,15 \text { observations }\end{array}$ & Gini index & $\begin{array}{l}\text { Income definitions change across countries } \\
\text { and overt time (the authors control for } \\
\text { defintional changes of the income definitions } \\
\text { through dummy variables) }\end{array}$ & $\begin{array}{l}\text { unemployment benefits }[-] \text { ] tax wedge }[-] \text {; } \\
\text { union density rate }[-] ; \text { minimum/median wage } \\
\text { ratio [-] }\end{array}$ & 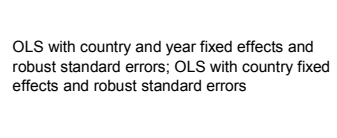 & $\begin{array}{l}\text { Results of unemployment benefits and } \\
\text { minimum/median wage broadld hold suing two two } \\
\text { different inequality datasests. However, results } \\
\text { of tax wedge and unioion density rate are in } \\
\text { general not significant in the alternative } \\
\text { datasest. }\end{array}$ \\
\hline de Groot et al. (2004) & $\begin{array}{l}18 \text { OECD countries, } 1960-1995 \text { (5-year-period } \\
\text { averages), } 95 \text { observations }\end{array}$ & $\ln ($ Gini index $)$ & $\begin{array}{l}\text { Gross household income inequality estimated } \\
\text { on the basis of ananufacturing pay inequality } \\
\text { and other controls }\end{array}$ & 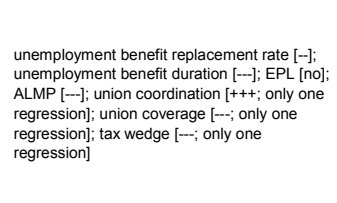 & OLS with robust standard errors & 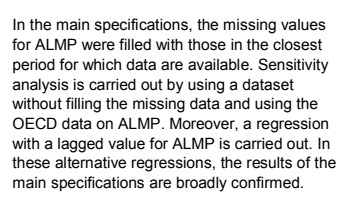 \\
\hline Galli and van der Hoeven (2001) & $\begin{array}{l}15 \text { OECD countries, 1973-1996, } 60 \\
\text { observations }\end{array}$ & Gini index & Net income at household level & $\begin{array}{l}\text { govermment expenditure (\%GDP) [--; only one } \\
\text { regression] }\end{array}$ & $\begin{array}{l}\text { o OLS with country fixed effects and robust } \\
\text { standard errors }\end{array}$ & \\
\hline Gustafsson and Johansson (1999) & $\begin{array}{l}16 \text { OECD countries, } 1966-1994,89 \\
\text { observations }\end{array}$ & Gini index & $\begin{array}{l}\text { Equivalent disposable income at household } \\
\text { level with the equivalence scale changing } \\
\text { across countries }\end{array}$ & $\begin{array}{l}\text { union density [-]; social security transfers } \\
(\% G D P) \text { [no]; public consumption (\%GDP) [--] }\end{array}$ & $\begin{array}{l}\text { OLS with country fixed effects and robust } \\
\text { a tandard errors; random-effect FGLS }\end{array}$ & 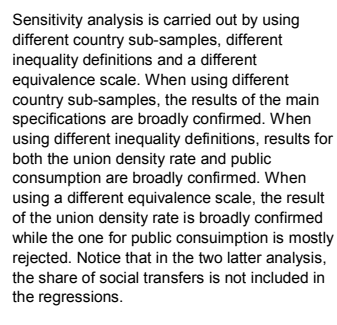 \\
\hline Mahler (2004) & $\begin{array}{l}16 \text { OECD countries, 1981-1992, } 35 \\
\text { observations }\end{array}$ & 9th/1st decile & $\begin{array}{l}\text { Equivalised disposable income at household } \\
\text { level }\end{array}$ & $\begin{array}{l}\text { union density [no; only one regression]; wage } \\
\text { coordination [no; only one regression] }\end{array}$ & OLS with robust standard errors & \\
\hline
\end{tabular}




\section{ECO/WKP(2006)28}

Table 11. Regression of the Gini coefficient against policies/institutions, 1978-2000

\begin{tabular}{|c|c|c|c|c|c|c|}
\hline & (1) & $(2)$ & (3) & (4) & $(5)$ & (6) \\
\hline & $\begin{array}{l}\text { OLS; robust } \\
\text { standard errors }\end{array}$ & $\begin{array}{l}\text { OLS with country } \\
\text { and time fixed } \\
\text { effects; robust } \\
\text { standard errors }\end{array}$ & $\begin{array}{l}\text { MLE with country } \\
\text { random effects } \\
\text { and time fixed } \\
\text { effects }\end{array}$ & $\begin{array}{c}\quad=(2) \\
\text { with social } \\
\text { expenditure }\end{array}$ & $\begin{array}{c}=(2) \\
\text { with ALMP }\end{array}$ & $\begin{array}{c}=(2) \\
\text { with 5-year } \\
\text { averages }\end{array}$ \\
\hline $\begin{array}{l}\text { Unemployment benefits' replacement rate and } \\
\text { duration index }\end{array}$ & $\begin{array}{l}-0.001656 \\
{[11.61]^{\star * *}}\end{array}$ & $\begin{array}{l}0.000145 \\
{[0.45]}\end{array}$ & $\begin{array}{c}-0.000044 \\
{[0.19]}\end{array}$ & $\begin{array}{c}0.000369 \\
{[0.75]}\end{array}$ & $\begin{array}{c}0.000285 \\
{[0.63]}\end{array}$ & $\begin{array}{c}-0.000252 \\
{[0.53]}\end{array}$ \\
\hline Union density & $\begin{array}{c}-0.001014 \\
{[9.75]^{\star * \star}}\end{array}$ & $\begin{array}{c}0.000011 \\
{[0.03]}\end{array}$ & $\begin{array}{c}-0.000391 \\
{[1.62]}\end{array}$ & $\begin{array}{c}0.000479 \\
{[0.77]}\end{array}$ & $\begin{array}{c}0.000724 \\
{[1.98]^{*}}\end{array}$ & $\begin{array}{c}0.000011 \\
{[0.02]}\end{array}$ \\
\hline Tax wedge (single-earner couple with 2 children) & $\begin{array}{c}-0.113431 \\
{[3.15]^{* * *}}\end{array}$ & $\begin{array}{c}0.071026 \\
{[1.54]}\end{array}$ & $\begin{array}{c}0.060972 \\
{[1.51]}\end{array}$ & & $\begin{array}{c}0.113768 \\
{[2.32]^{\star *}}\end{array}$ & $\begin{array}{c}-0.039847 \\
{[0.44]}\end{array}$ \\
\hline Capital per worker (log) & $\begin{array}{c}0.020141 \\
{[2.15]^{\star *}}\end{array}$ & $\begin{array}{c}-0.029547 \\
{[1.83]^{*}}\end{array}$ & $\begin{array}{c}-0.032802 \\
{[2.73]^{\star \star *}}\end{array}$ & $\begin{array}{c}-0.007013 \\
{[0.41]}\end{array}$ & $\begin{array}{c}-0.016284 \\
{[0.80]}\end{array}$ & $\begin{array}{c}-0.004250 \\
{[0.23]}\end{array}$ \\
\hline Average years of education & $\begin{array}{l}-0.005213 \\
{[4.37]^{\star * *}}\end{array}$ & $\begin{array}{c}0.005221 \\
{[0.83]}\end{array}$ & $\begin{array}{c}0.002167 \\
{[0.63]}\end{array}$ & $\begin{array}{c}-0.004997 \\
{[0.74]}\end{array}$ & $\begin{array}{c}-0.007121 \\
{[1.27]}\end{array}$ & $\begin{array}{c}0.008453 \\
{[0.98]}\end{array}$ \\
\hline Social expenditure ( $\%$ of GDP) & & & & $\begin{array}{c}-0.001062 \\
{[0.79]}\end{array}$ & & \\
\hline $\begin{array}{l}\text { ALMP spending, per unemployed (\% of per } \\
\text { capita GDP) }\end{array}$ & & & & & $\begin{array}{l}-0.000148 \\
{[2.51]^{* \star}}\end{array}$ & \\
\hline Output gap & & & & $\begin{array}{c}-0.000271 \\
{[0.30]}\end{array}$ & $\begin{array}{c}0.000974 \\
{[1.61]}\end{array}$ & \\
\hline Constant & $\begin{array}{c}0.231426 \\
{[2.44]^{\star \star}}\end{array}$ & $\begin{array}{l}0.513591 \\
{[2.75]^{\star * \star}}\end{array}$ & $\begin{array}{c}0.592640 \\
{[4.71]^{\star * *}}\end{array}$ & $\begin{array}{c}0.421265 \\
{[2.07]^{\star *}}\end{array}$ & $\begin{array}{c}0.513255 \\
{[2.40]^{\star *}}\end{array}$ & $\begin{array}{c}0.250136 \\
{[1.21]}\end{array}$ \\
\hline Country dummies & no & yes & no & yes & yes & yes \\
\hline Year dummies & no & yes & yes & yes & yes & yes \\
\hline Observations & 181 & 181 & 181 & 164 & 140 & 79 \\
\hline
\end{tabular}


$\mathrm{ECO} / \mathrm{WKP}(2006) 28$

Table 12. Mean and standard deviation of Gini coefficient and explanatory variables, 1978-2000

\begin{tabular}{|c|c|c|c|}
\hline & Mean & & \\
\hline Gini coefficient & 0.28 & $\begin{array}{l}\text { overall } \\
\text { between-country } \\
\text { within-country }\end{array}$ & $\begin{array}{l}0.04 \\
0.04 \\
0.01\end{array}$ \\
\hline $\begin{array}{l}\text { Index of unemployment benefit } \\
\text { replacement rate and duration }\end{array}$ & 28.93 & $\begin{array}{l}\text { overall } \\
\text { between-country } \\
\text { within-country }\end{array}$ & $\begin{array}{c}13.41 \\
12.81 \\
3.97\end{array}$ \\
\hline Union density & 39.30 & $\begin{array}{l}\text { overall } \\
\text { between-country } \\
\text { within-country }\end{array}$ & $\begin{array}{c}21.22 \\
20.56 \\
3.43\end{array}$ \\
\hline Tax wedge & 0.32 & $\begin{array}{l}\text { overall } \\
\text { between-country } \\
\text { within-country }\end{array}$ & $\begin{array}{l}0.08 \\
0.08 \\
0.02\end{array}$ \\
\hline Capital per worker (log) & 11.51 & $\begin{array}{l}\text { overall } \\
\text { between-country } \\
\text { within-country }\end{array}$ & $\begin{array}{l}0.35 \\
0.33 \\
0.15\end{array}$ \\
\hline Average years of education & 11.03 & $\begin{array}{l}\text { overall } \\
\text { between-country } \\
\text { within-country }\end{array}$ & $\begin{array}{l}1.41 \\
1.34 \\
0.50 \\
\end{array}$ \\
\hline
\end{tabular}

Notes: The countries considered in the calculation of these statistics are the United States, Japan, Canada, Australia,

Norway and the EU-15 countries excluding Luxembourg and Portugal. See Annex 3 for definitions of the variables. 
ECO/WKP(2006)28

Table 13. Specification tests for the Gini coefficient model

Test for the $\mathrm{H}_{0}$ of no country and time heterogeneity

$\begin{array}{lll}F(38,137) & = & 25.97\end{array}$

$\mathrm{p}$ value $\quad<\quad 0.00$

Test for the $\mathrm{H}_{0}$ of no country heterogeneity given time heterogeneity

$\begin{array}{llc}\mathrm{F}(18,137) & = & 39.56 \\ \mathrm{p} \text { value } & < & 0.00\end{array}$

Test for the $\mathrm{H}_{0}$ of no time heterogeneity given country heterogeneity

$\begin{array}{lll}\mathrm{F}(20,137) & = & 1.91 \\ \mathrm{p} \text { value } & = & 0.02\end{array}$

Notes: The countries considered in the calculation of these tests are the United States, Japan, Canada, Australia,

Norway and the EU-15 countries excluding Luxembourg and Portugal. The estimation period is 1978-2000. 
ECO/WKP(2006)28

Table 14. Regression of 9th-to-1st decile ratio against policies/institutions, 1978-2000

\begin{tabular}{|c|c|c|c|c|c|c|}
\hline & (1) & (2) & (3) & (4) & (5) & (6) \\
\hline & $\begin{array}{l}\text { OLS; robust } \\
\text { standard errors }\end{array}$ & $\begin{array}{l}\text { GLS with country } \\
\text { random effects; } \\
\text { robust standard } \\
\text { errors }\end{array}$ & $\begin{array}{l}\text { OLS with country } \\
\text { fixed effects; } \\
\text { robust standard } \\
\text { errors }\end{array}$ & $\begin{array}{c}=(2) \\
\text { with social } \\
\text { expenditure }\end{array}$ & $\begin{array}{c}=(2) \\
\text { with ALMP }\end{array}$ & $\begin{array}{c}=(2) \\
\text { with 5-year } \\
\text { averages }\end{array}$ \\
\hline $\begin{array}{l}\text { Unemployment benefits' replacement rate and } \\
\text { duration index }\end{array}$ & $\begin{array}{l}-0.034189 \\
{[10.97]^{* \star *}}\end{array}$ & $\begin{array}{c}0.000011 \\
{[0.00]}\end{array}$ & $\begin{array}{c}0.005785 \\
{[1.24]}\end{array}$ & $\begin{array}{c}-0.003328 \\
{[0.41]}\end{array}$ & $\begin{array}{l}-0.021699 \\
{[3.69]^{* * *}}\end{array}$ & $\begin{array}{c}-0.018712 \\
{[2.23]^{\star *}}\end{array}$ \\
\hline Union density & $\begin{array}{l}-0.019303 \\
{[10.55]^{* * *}}\end{array}$ & $\begin{array}{c}-0.021174 \\
{[4.29]^{\star * \star}}\end{array}$ & $\begin{array}{c}-0.017142 \\
{[2.28]^{\star *}}\end{array}$ & $\begin{array}{c}-0.020118 \\
{[4.23]^{\star \star \star}}\end{array}$ & $\begin{array}{c}-0.012151 \\
{[2.36]^{* *}}\end{array}$ & $\begin{array}{c}-0.018541 \\
{[3.24]^{\star * \star}}\end{array}$ \\
\hline Tax wedge (single-earner couple with 2 children) & $\begin{array}{l}-3.027490 \\
{[4.88]^{* * *}}\end{array}$ & $\begin{array}{c}-0.182769 \\
{[0.30]}\end{array}$ & $\begin{array}{c}0.349372 \\
{[0.49]}\end{array}$ & & $\begin{array}{c}0.439941 \\
{[0.80]}\end{array}$ & $\begin{array}{c}-2.962244 \\
{[2.56]^{\star *}}\end{array}$ \\
\hline Capital per worker (log) & $\begin{array}{l}0.418060 \\
{[2.67]^{\star * *}}\end{array}$ & $\begin{array}{c}0.007545 \\
{[0.05]}\end{array}$ & $\begin{array}{c}-0.088352 \\
{[0.48]}\end{array}$ & $\begin{array}{c}0.278922 \\
{[1.46]}\end{array}$ & $\begin{array}{c}0.290528 \\
{[1.43]}\end{array}$ & $\begin{array}{c}0.531193 \\
{[2.21]^{\star *}}\end{array}$ \\
\hline Average years of education & $\begin{array}{l}-0.080943 \\
{[3.12]^{\star * *}}\end{array}$ & $\begin{array}{c}0.072851 \\
{[1.16]}\end{array}$ & $\begin{array}{c}0.111156 \\
{[1.70]^{*}}\end{array}$ & $\begin{array}{c}0.042328 \\
{[0.59]}\end{array}$ & $\begin{array}{c}-0.026439 \\
{[0.44]}\end{array}$ & $\begin{array}{c}-0.042840 \\
{[0.57]}\end{array}$ \\
\hline Social expenditure (\% of GDP) & & & & $\begin{array}{c}-0.055167 \\
{[4.16]^{\star \star \star}}\end{array}$ & & \\
\hline $\begin{array}{l}\text { ALMP spending, per unemployed (\% of per } \\
\text { capita GDP) }\end{array}$ & & & & & $\begin{array}{c}-0.000573 \\
{[0.88]}\end{array}$ & \\
\hline Output gap & & & & $\begin{array}{l}-0.020770 \\
{[2.01]^{\star *}}\end{array}$ & $\begin{array}{c}0.007622 \\
{[0.88]}\end{array}$ & \\
\hline Constant & $\begin{array}{c}2.498265 \\
{[1.53]}\end{array}$ & $\begin{array}{l}3.685274 \\
{[2.58]^{* * *}}\end{array}$ & $\begin{array}{l}3.998219 \\
{[2.21]^{* *}}\end{array}$ & $\begin{array}{c}2.059211 \\
{[1.36]}\end{array}$ & $\begin{array}{c}1.677394 \\
{[0.89]}\end{array}$ & $\begin{array}{c}0.296257 \\
{[0.14]}\end{array}$ \\
\hline Country dummies & no & no & yes & no & no & no \\
\hline Year dummies & no & no & no & no & no & no \\
\hline Observations & 181 & 181 & 181 & 164 & 140 & 79 \\
\hline
\end{tabular}

* significant at $10 \%$; ** significant at $5 \%$; ${ }^{* * *}$ significant at $1 \%$

Notes: In columns (1)-(5), the regressions use an (unbalanced) panel of OECD countries comprising the United States, Japan, Canada, Australia, Norway and the EU-15 countries excluding Luxembourg and Portugal. In column (6), also Portugal is included in the regression. In column (4), the estimation period is 1980-2000 and in column (5) it is $1985-2000$. See Annex 3 for the definition of the explanatory variables. 
Table 15. Indicators of poverty risk Waves 1994-2001 ${ }^{a}$

Panel A. Indicators of poverty incidence, dynamics and duration

\begin{tabular}{|c|c|c|c|c|c|c|}
\hline & 1 & 2 & 3 & 4 & 5 & 6 \\
\hline & $\begin{array}{c}\text { Average } \\
\text { poverty rate }\end{array}$ & $\begin{array}{l}\text { Average } \\
\text { entry rate }\end{array}$ & $\begin{array}{l}\text { Average } \\
\text { exit rate }\end{array}$ & $\begin{array}{l}\text { At-least-once- } \\
\text { poverty rate }\end{array}$ & $\begin{array}{c}\text { Average time } \\
\text { spent in poverty by } \\
\text { individuals ever } \\
\text { poor }\end{array}$ & $\begin{array}{l}\text { Average duration } \\
\text { of uncensored } \\
\text { poverty spells }\end{array}$ \\
\hline & $\%$ population & $\%$ non-poor $(\mathrm{t}-1)$ & $\%$ poor $(\mathrm{t}-1)$ & $\%$ population & $\%$ total years & years \\
\hline Denmark & 5.8 & 3.7 & 55.0 & 18.3 & 24.0 & 1.3 \\
\hline Finland & 5.9 & 3.2 & 38.7 & 13.4 & 38.3 & 1.4 \\
\hline Sweden & 6.2 & .. & .. & .. & .. & .. \\
\hline Netherlands & 6.2 & 3.3 & 56.1 & 18.7 & 27.0 & 1.4 \\
\hline Luxembourg & 6.3 & 2.5 & 43.6 & 14.5 & 37.1 & 1.5 \\
\hline Germany & 8.0 & 3.3 & 44.1 & 19.9 & 31.0 & 1.4 \\
\hline Austria & 8.0 & 3.6 & 44.1 & 20.8 & 36.2 & 1.5 \\
\hline Belgium & 8.4 & 4.0 & 44.8 & 23.4 & 30.9 & 1.4 \\
\hline France & 8.7 & 4.3 & 45.9 & 23.9 & 29.9 & 1.4 \\
\hline $\mathrm{EU}^{-\mathrm{ECHP}^{D}}$ & 10.7 & 4.9 & 43.2 & 28.2 & 33.9 & 1.5 \\
\hline Italy & 12.6 & 5.8 & 43.3 & 34.0 & 36.3 & 1.5 \\
\hline Ireland & 12.9 & 5.5 & 32.6 & 33.9 & 39.2 & 1.5 \\
\hline United Kingdom & 13.0 & 5.9 & 41.8 & 32.1 & 35.4 & 1.5 \\
\hline Spain & 13.3 & 7.0 & 46.3 & 37.7 & 34.5 & 1.5 \\
\hline Portugal & 14.9 & 5.2 & 33.4 & 37.0 & 41.6 & 1.5 \\
\hline Greece & 15.1 & 7.0 & 40.5 & 40.3 & 38.2 & 1.5 \\
\hline United States & 17.6 & 6.7 & 37.9 & 30.7 & 42.2 & 1.8 \\
\hline
\end{tabular}

Panel B. Indicators of poverty persistence

\begin{tabular}{|c|c|c|c|c|c|}
\hline & 7 & 8 & 9 & 10 & 11 \\
\hline & \multicolumn{2}{|c|}{ Chronic poverty } & \multirow{2}{*}{$\begin{array}{c}\begin{array}{c}\text { Chronic poor } \\
\text { with exits }\end{array} \\
\% \text { chronic poor }\end{array}$} & \multicolumn{2}{|c|}{ Always-poor } \\
\hline & $\%$ population & $\begin{array}{c}\% \text { at-least-once- } \\
\text { poor }\end{array}$ & & $\%$ population & $\%$ chronic poor \\
\hline Denmark & 1.3 & 7.4 & 94.4 & 0.1 & 5.6 \\
\hline Finland & 2.6 & 19.4 & 72.4 & 0.7 & 27.6 \\
\hline Sweden & .. & .. & .. & .. & .. \\
\hline Netherlands & 3.0 & 16.3 & 96.1 & 0.1 & 3.9 \\
\hline Luxembourg & 3.0 & 20.7 & 65.4 & 1.0 & 34.6 \\
\hline Germany & 3.4 & 16.9 & 76.9 & 0.8 & 23.1 \\
\hline Austria & 4.2 & 20.4 & 75.9 & 1.0 & 24.1 \\
\hline Belgium & 3.8 & 16.2 & 81.8 & 0.7 & 18.2 \\
\hline France & 4.1 & 17.3 & 81.3 & 0.8 & 18.7 \\
\hline $\mathrm{EU}^{-\mathrm{ECHP}^{D}}$ & 6.2 & 22.0 & 84.7 & 1.0 & 15.3 \\
\hline Italy & 9.6 & 28.4 & 90.0 & 1.0 & 10.0 \\
\hline Ireland & 8.8 & 26.0 & 72.1 & 2.5 & 27.9 \\
\hline United Kingdom & 6.8 & 21.1 & 83.0 & 1.2 & 17.0 \\
\hline Spain & 8.8 & 23.3 & 92.7 & 0.6 & 7.3 \\
\hline Portugal & 12.5 & 33.7 & 75.6 & 3.0 & 24.4 \\
\hline Greece & 10.8 & 26.9 & 75.8 & 2.6 & 24.2 \\
\hline United States & 8.6 & 28.1 & 64.1 & 3.1 & 35.9 \\
\hline
\end{tabular}

a) 1995-2001 for Austria and Luxembourg, 1996-2001 for Finland, 1997-2001 for Sweden and 1994-1997 and waves 1999 and 2001 for the US. For the calculation of the average poverty rate, all individuals interviewed in each year are considered. For average entry and exit rates, only individuals interviewed in at least two consecutive years are considered. For the other indicators, only individuals interviewed during the whole period are considered. For Sweden, indicators of poverty dynamics are not available as the ECHP dataset for Sweden is not longitudinal.

b) EU/ECHP refers to the weighted average of the EU countries participating to all ECHP waves, i.e. the EU-15 excluding Austria, Finland, Luxembourg and Sweden.

Source: European Community Household Panel (ECHP) data set and Cross National Equivalent Files (CNEF) data set. 
Table 16. Cross-correlations of poverty measures

1994-2001 waves

\begin{tabular}{|c|c|c|c|c|c|c|c|c|}
\hline & $\begin{array}{c}\text { Average } \\
\text { poverty rate }\end{array}$ & Always poor & $\begin{array}{l}\text { Poor at least } \\
\text { once }\end{array}$ & Chronic poor & $\begin{array}{l}\text { Average } \\
\text { entry rate }\end{array}$ & $\begin{array}{l}\text { Average exit } \\
\text { rate }\end{array}$ & $\begin{array}{l}\text { Average } \\
\text { share of time } \\
\text { spent in } \\
\text { poverty }\end{array}$ & $\begin{array}{c}\text { Average } \\
\text { duration of } \\
\text { uncensored } \\
\text { poverty } \\
\text { spells }\end{array}$ \\
\hline Average poverty rate & 1.00 & & & & & & & \\
\hline Always poor & $0.82^{* * *}$ & 1.00 & & & & & & \\
\hline Poor at least once & $0.90^{\star \star \star}$ & 0.64 ** & 1.00 & & & & & \\
\hline Long-run poor & $0.91^{\star \star \star}$ & $0.78^{\star \star \star}$ & $0.94^{\star \star \star}$ & 1.00 & & & & \\
\hline Average entry rate & $0.92 * * *$ & 0.58 ** & $0.93^{* * *}$ & $0.84^{* * *}$ & 1.00 & & & \\
\hline Average exit rate & $-0.61^{* *}$ & $-0.81^{* * *}$ & $-0.47 *$ & $-0.64^{* * *}$ & -0.38 & 1.00 & & \\
\hline Average share of time spent in poverty & $0.67^{* * *}$ & $0.82^{* * *}$ & $0.48^{*}$ & $0.69 * * *$ & 0.46 * & $-0.90^{* * *}$ & 1.00 & \\
\hline Average duration of uncensored poverty spells & $0.82 * * *$ & $0.81^{* \star *}$ & 0.54 ** & $0.64^{* *}$ & $0.61^{* *}$ & -0.64 ** & $0.76^{* * *}$ & 1.00 \\
\hline
\end{tabular}

* significant at $10 \%$; ** significant at $5 \%$; *** significant at $1 \%$

Source: European Community Household Panel (ECHP) data set and Cross National Equivalent Files (CNEF) data set. 
Table 17. Income mobility of 1994-wave poor exiting poverty in 1995 wave per cent

\begin{tabular}{|c|c|c|c|c|}
\hline & \multicolumn{4}{|c|}{$\begin{array}{l}\text { Share of persons poor in } 1994 \text { wave }^{a} \text { and exiting poverty in } 1995 \text { wave }{ }^{b} \text { with 1995- } \\
2001 \text { wave }^{c} \text { average income: }\end{array}$} \\
\hline & 1 & 2 & 3 & 4 \\
\hline & Below poverty line & $\begin{array}{l}\text { Between poverty line } \\
\text { and median }\end{array}$ & Above median & Total \\
\hline Germany & 5.8 & 76.8 & 17.4 & 100 \\
\hline Luxembourg & 5.8 & 85.1 & 9.0 & 100 \\
\hline France & 7.4 & 55.1 & 37.5 & 100 \\
\hline Austria & 9.4 & 73.1 & 17.5 & 100 \\
\hline Netherlands & 9.6 & 64.0 & 26.4 & 100 \\
\hline Ireland & 10.5 & 59.7 & 29.7 & 100 \\
\hline Belgium & 11.2 & 69.3 & 19.6 & 100 \\
\hline Denmark & 11.3 & 56.7 & 32.0 & 100 \\
\hline EU/ECHP & 12.7 & 64.3 & 23.0 & 100 \\
\hline Portugal & 13.0 & 73.0 & 13.9 & 100 \\
\hline United Kingdom & 13.2 & 63.0 & 23.8 & 100 \\
\hline Italy & 16.1 & 64.5 & 19.4 & 100 \\
\hline Greece & 17.3 & 67.7 & 15.0 & 100 \\
\hline United States & 17.5 & 57.9 & 24.6 & 100 \\
\hline Finland & 17.7 & 72.6 & 9.7 & 100 \\
\hline Spain & 19.0 & 57.6 & 23.5 & 100 \\
\hline
\end{tabular}

a) 1995 wave for Austria and Luxembourg, and 1996 wave for Finland.

b) 1996 wave for Austria and Luxembourg, and 1997 wave for Finland.

c) 1996-2001 waves for Austria and Luxembourg, 1997-2001 waves for Finland, and 1995-1997 and waves 1999 and 2001 for the US.

Source: European Community Household Panel (ECHP) data set and Cross National Equivalent Files (CNEF) data set. 
Table 18. Relative risk of poverty"

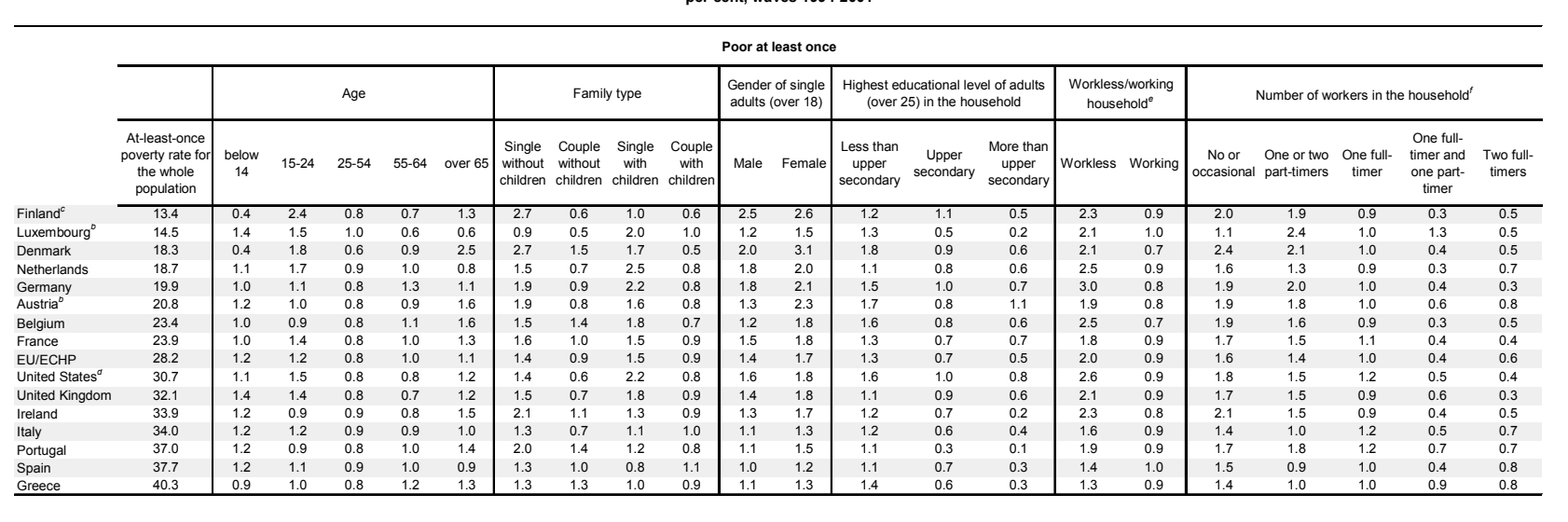

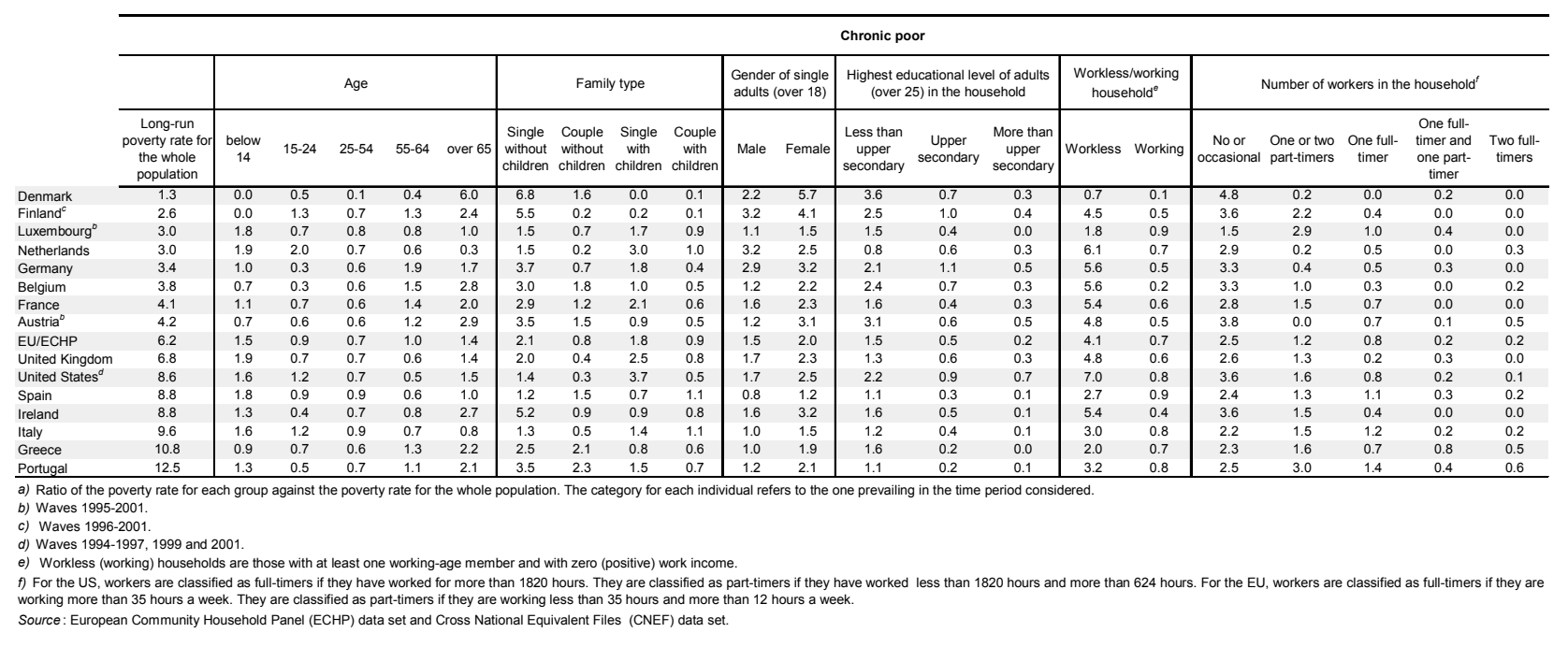


ECO/WKP(2006)28

Table 19. Correlations of poverty measures with labour market aggregates ${ }^{a}$

1993-2000

\begin{tabular}{|c|c|c|c|}
\hline & Poverty rate & Entry rate & Exit rate \\
\hline Participation rate - total & $-0.37^{* * *}$ & $-0.36 * * *$ & 0.22 ** \\
\hline Participation rate - male & -0.02 & 0.03 & $0.25 * *$ \\
\hline Participation rate - female & $-0.45^{* * *}$ & $-0.47^{* * *}$ & 0.17 \\
\hline Employment rate - total & $-0.34 * * *$ & $-0.38^{* * *}$ & 0.18 * \\
\hline Employment rate - male & -0.03 & -0.06 & $0.24^{* *}$ \\
\hline Employment rate - female & $-0.42 * * *$ & $-0.47^{* \star *}$ & 0.13 \\
\hline Unemployment rate - total & 0.15 & $0.32 * * *$ & 0.00 \\
\hline Unemployment rate - male & 0.02 & 0.18 * & -0.09 \\
\hline Unemployment rate - female & 0.24 ** & $0.41^{* * *}$ & 0.06 \\
\hline Long-term unemployment rate - total & 0.22 ** & $0.36 * * *$ & -0.03 \\
\hline Long-term unemployment rate - male & 0.08 & 0.21 ** & -0.11 \\
\hline Long-term unemployment rate - female & $0.29^{* * *}$ & $0.44^{* * *}$ & 0.03 \\
\hline
\end{tabular}

* significant at $10 \% ;{ }^{* *}$ significant at $5 \%$; ${ }^{* * *}$ significant at $1 \%$

a) Both poverty and labour market variables have been adjusted for the cycle. Labour market aggregates refer to working age population (15-64 age group).

Source : European Community Household Panel (ECHP) data set and Cross National Equivalent Files (CNEF) data set, OECD Employment Outlook. 
ECO/WKP(2006)28

Table 20. Regression of poverty rate against policies/institutions, 1978-2000

\begin{tabular}{|c|c|c|c|c|c|c|}
\hline & (1) & (2) & (3) & (4) & (5) & (6) \\
\hline & $\begin{array}{l}\text { OLS; robust } \\
\text { standard errors }\end{array}$ & $\begin{array}{l}\text { OLS with country } \\
\text { and time fixed } \\
\text { effects; robust } \\
\text { standard errors }\end{array}$ & $\begin{array}{l}\text { MLE with country } \\
\text { random effects } \\
\text { and time fixed } \\
\text { effects }\end{array}$ & $\begin{array}{c}\quad=(2) \\
\text { with social } \\
\text { expenditure }\end{array}$ & $\begin{array}{c}\quad=(2) \\
\text { with ALMP }\end{array}$ & $\begin{array}{l}\quad=(2) \\
\text { with 5-year } \\
\text { averages }\end{array}$ \\
\hline $\begin{array}{l}\text { Unemployment benefits' replacement rate and } \\
\text { duration index }\end{array}$ & $\begin{array}{l}-0.001567 \\
{[11.53]^{* * *}}\end{array}$ & $\begin{array}{c}0.000204 \\
{[0.85]}\end{array}$ & $\begin{array}{c}0.000154 \\
{[0.71]}\end{array}$ & $\begin{array}{c}0.000134 \\
{[0.34]}\end{array}$ & $\begin{array}{c}-0.000211 \\
{[0.38]}\end{array}$ & $\begin{array}{c}-0.000392 \\
{[1.20]}\end{array}$ \\
\hline Union density & $\begin{array}{l}-0.000824 \\
{[9.02]^{* \star *}}\end{array}$ & $\begin{array}{l}-0.001496 \\
{[4.20]^{\star \star *}}\end{array}$ & $\begin{array}{l}-0.001267 \\
{[5.37]^{\star \star *}}\end{array}$ & $\begin{array}{l}-0.001409 \\
{[2.86]^{\star \star *}}\end{array}$ & $\begin{array}{c}-0.000529 \\
{[0.96]}\end{array}$ & $\begin{array}{c}-0.000751 \\
{[1.94]^{*}}\end{array}$ \\
\hline Tax wedge (single-earner couple with 2 children) & $\begin{array}{l}-0.221998 \\
{[7.58]^{\star \star *}}\end{array}$ & $\begin{array}{c}-0.063337 \\
{[1.77]^{*}}\end{array}$ & $\begin{array}{c}-0.081289 \\
{[2.06]^{* *}}\end{array}$ & & $\begin{array}{c}-0.019662 \\
{[0.44]}\end{array}$ & $\begin{array}{c}-0.166302 \\
{[2.63]^{* *}}\end{array}$ \\
\hline Capital per worker (log) & $\begin{array}{l}0.027330 \\
{[4.05]^{* \star *}}\end{array}$ & $\begin{array}{c}-0.015935 \\
{[1.25]}\end{array}$ & $\begin{array}{c}-0.009622 \\
{[0.78]}\end{array}$ & $\begin{array}{c}0.013638 \\
{[0.84]}\end{array}$ & $\begin{array}{c}0.006408 \\
{[0.32]}\end{array}$ & $\begin{array}{c}-0.001241 \\
{[0.07]}\end{array}$ \\
\hline Average years of education & $\begin{array}{c}-0.005231 \\
{[4.61]^{* * *}}\end{array}$ & $\begin{array}{l}0.013888 \\
{[2.85]^{\star \star \star}}\end{array}$ & $\begin{array}{c}0.006992 \\
{[1.84]^{*}}\end{array}$ & $\begin{array}{c}0.006564 \\
{[1.03]}\end{array}$ & $\begin{array}{c}0.004755 \\
{[0.57]}\end{array}$ & $\begin{array}{l}0.026203 \\
{[4.36]^{* * *}}\end{array}$ \\
\hline Social expenditure ( $\%$ of GDP) & & & & $\begin{array}{c}-0.003461 \\
{[3.80]^{* * *}}\end{array}$ & & \\
\hline $\begin{array}{l}\text { ALMP spending, per unemployed (\% of per } \\
\text { capita GDP) }\end{array}$ & & & & & $\begin{array}{c}-0.000023 \\
{[0.34]}\end{array}$ & \\
\hline Output gap & & & & $\begin{array}{c}0.000864 \\
{[1.28]}\end{array}$ & $\begin{array}{c}0.001830 \\
{[2.73]^{\star * *}}\end{array}$ & \\
\hline Constant & $\begin{array}{c}-0.013184 \\
{[0.19]}\end{array}$ & $\begin{array}{c}0.165914 \\
{[1.17]}\end{array}$ & $\begin{array}{c}0.191706 \\
{[1.50]}\end{array}$ & $\begin{array}{c}-0.028214 \\
{[0.17]}\end{array}$ & $\begin{array}{c}0.004751 \\
{[0.02]}\end{array}$ & $\begin{array}{c}-0.111418 \\
{[0.64]}\end{array}$ \\
\hline Country dummies & no & yes & no & yes & yes & yes \\
\hline Year dummies & no & yes & yes & yes & yes & yes \\
\hline Observations & 178 & 178 & 178 & 162 & 139 & 78 \\
\hline
\end{tabular}


Figure 1. Indicators of income inequality and relative poverty, $2001^{a}$

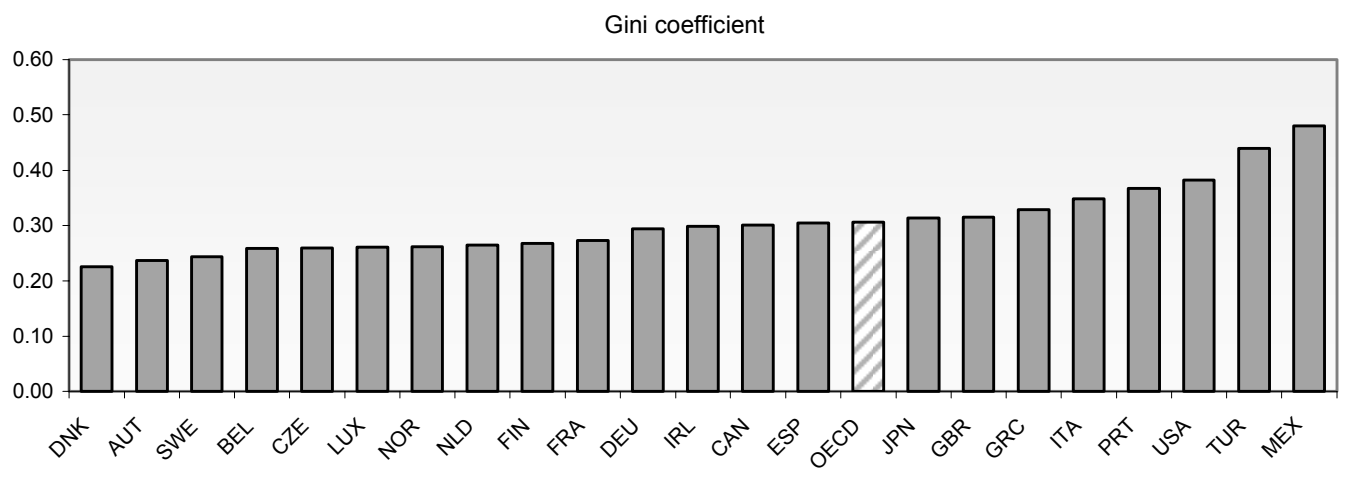

9 th to 1 st decile ratio

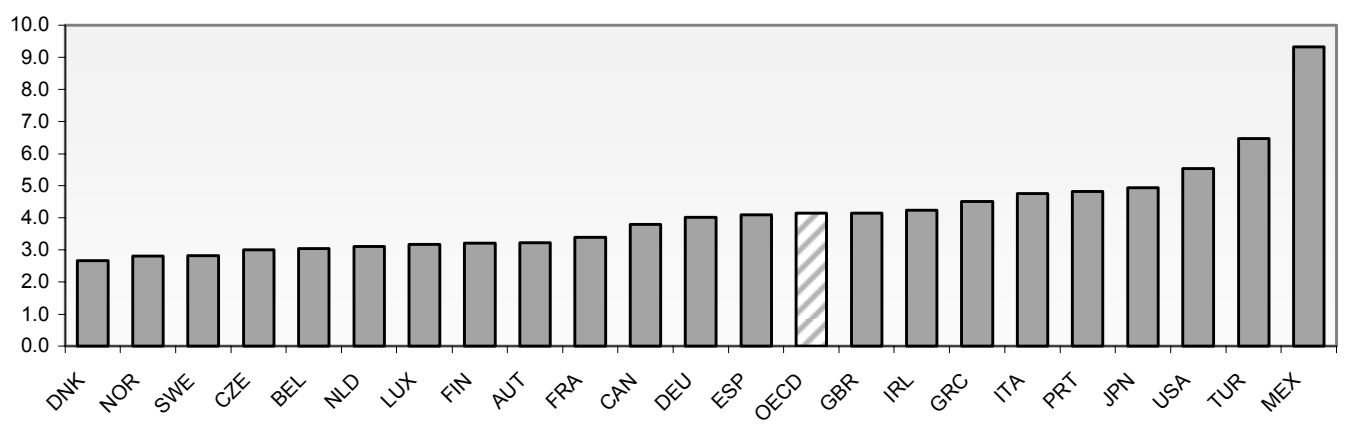

Median to 1 st decile ratio

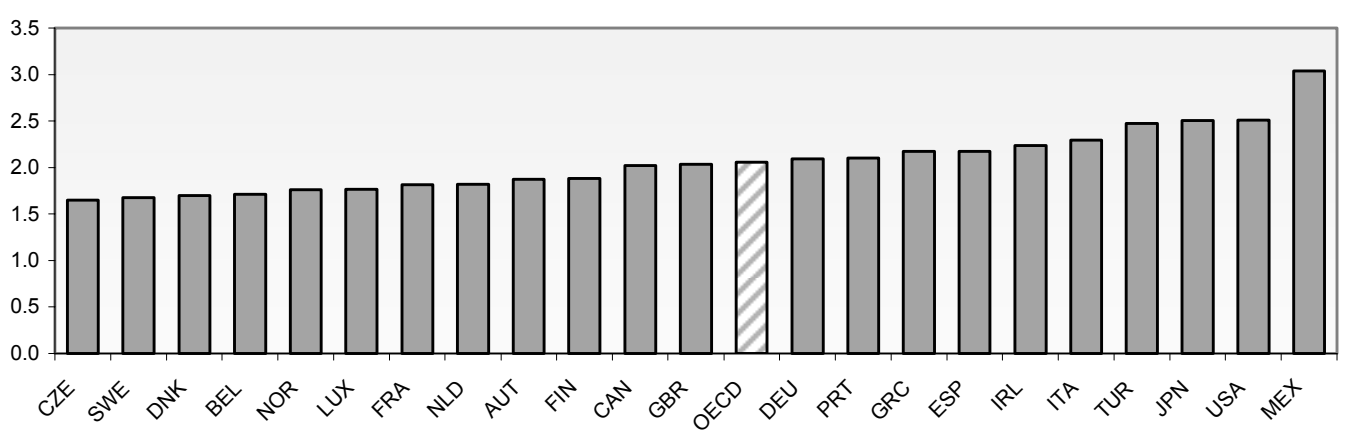

Relative poverty rate

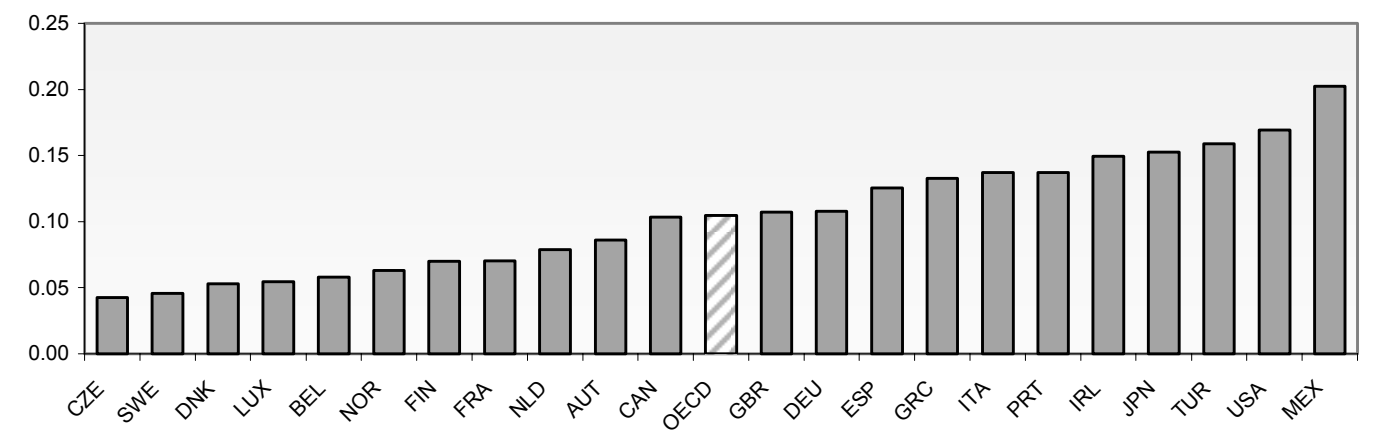

a) 2000 for Canada, France, Japan and Norway and 2002 for Czech Republic, Germany, Mexico and Turkey.

Source: Förster and Mira d'Ercole (2005). 
ECO/WKP(2006)28

Figure 2. Evolution of disposable income inequality ${ }^{a}$ across OECD countries

Panel A. 1984-1994

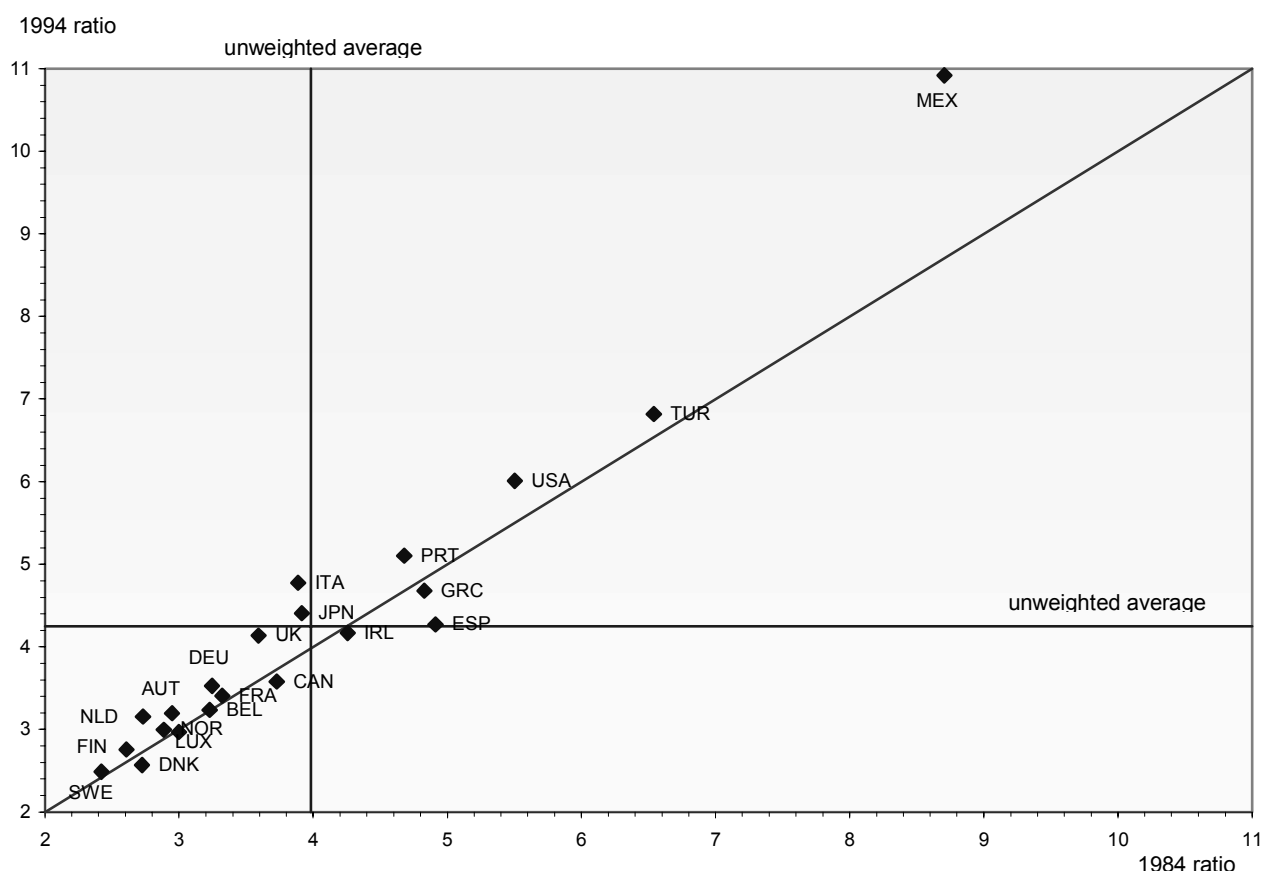

Panel B. 1994-2001 ${ }^{c}$

2001 ratio

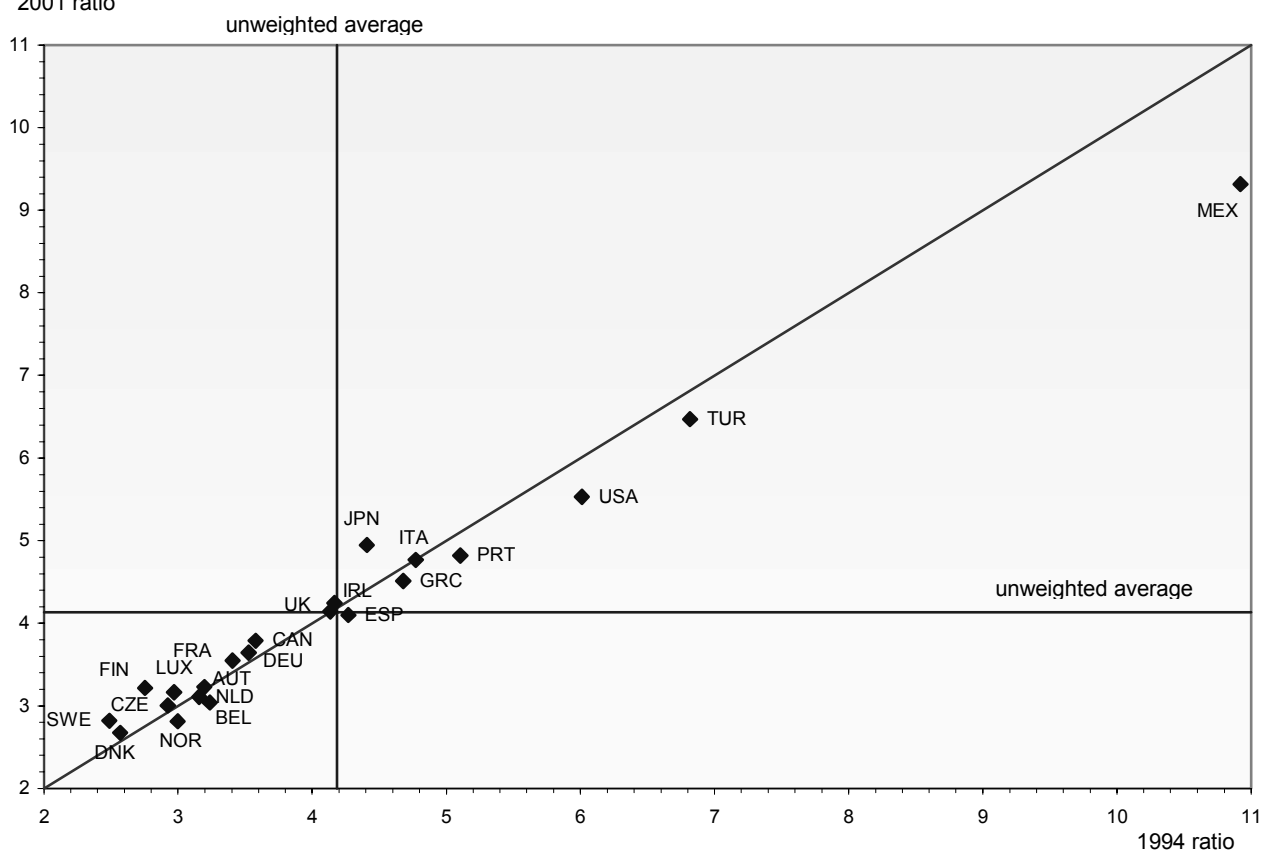

a) As measured by the ratio of the $9^{\text {th }}$-to- $1^{\text {st }}$ decile.

b) 1983-1994 for Austria and Denmark, 1983-1995 for Sweden, 1984-1995 for Italy, 1985-1994 for Japan, Luxembourg,

Netherlands, Spain and United Kingdom, 1985-1995 for Belgium and Canada, 1986-1995 for Finland and Norway,

1987-1994 for Ireland and Turkey, 1988-1994 for Greece, 1990-1995 for Portugal.

c) 1994-2000 for Japan, 1994-2002 for Mexico and Turkey, 1995-2000 for Canada and Norway,

1995-2001 for Belgium, Finland, Italy, Portugal and Sweden, 1996-2002 for Czech Republic.

Sources: Förster and Mira d'Ercole (2005), Luxembourg Income Study (LIS) data set, European Community Household Panel (ECHP) data set and Cross National Equivalent Files (CNEF) data set. 
Figure 3. Evolution of relative poverty rates ${ }^{a}$ across OECD countries

\section{Panel A. 1984-1994}

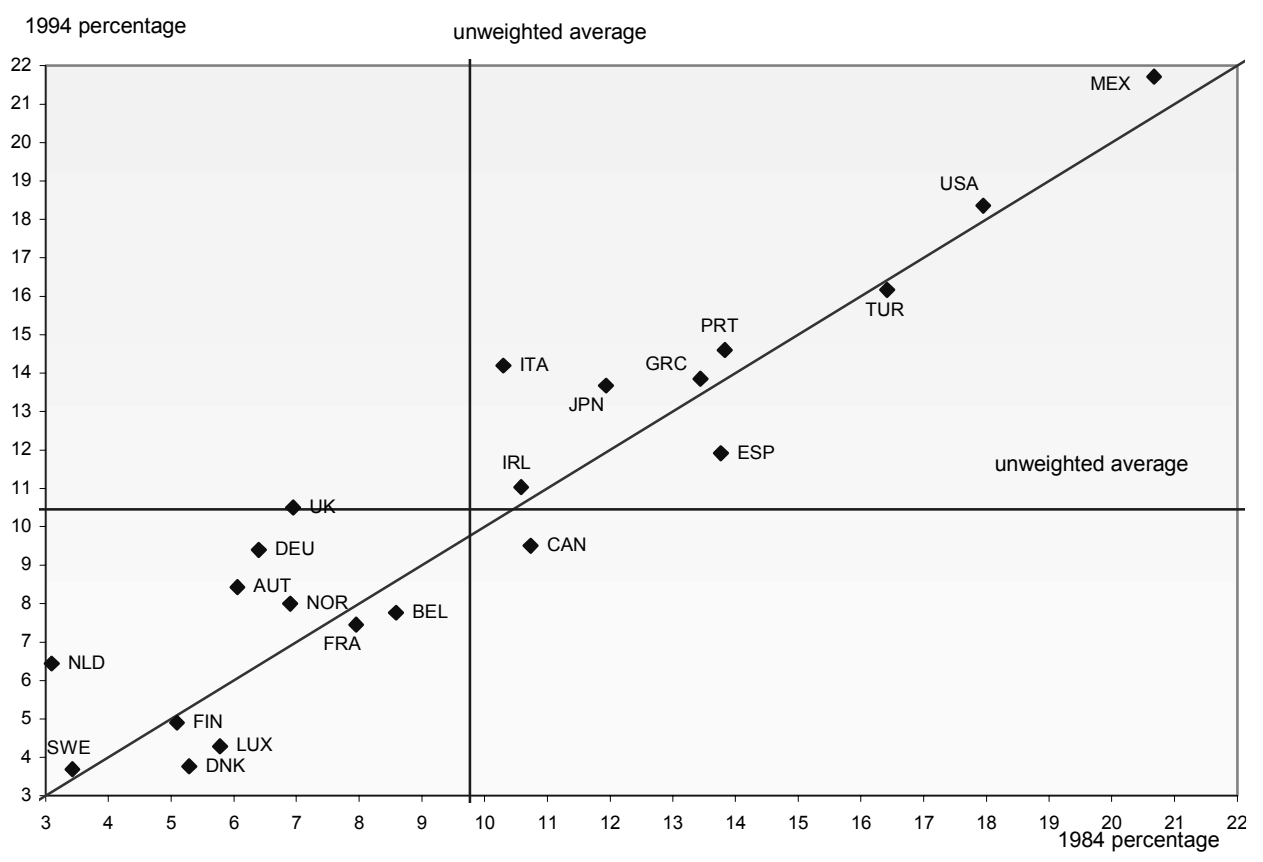

Panel B. 1994-2001 ${ }^{c}$

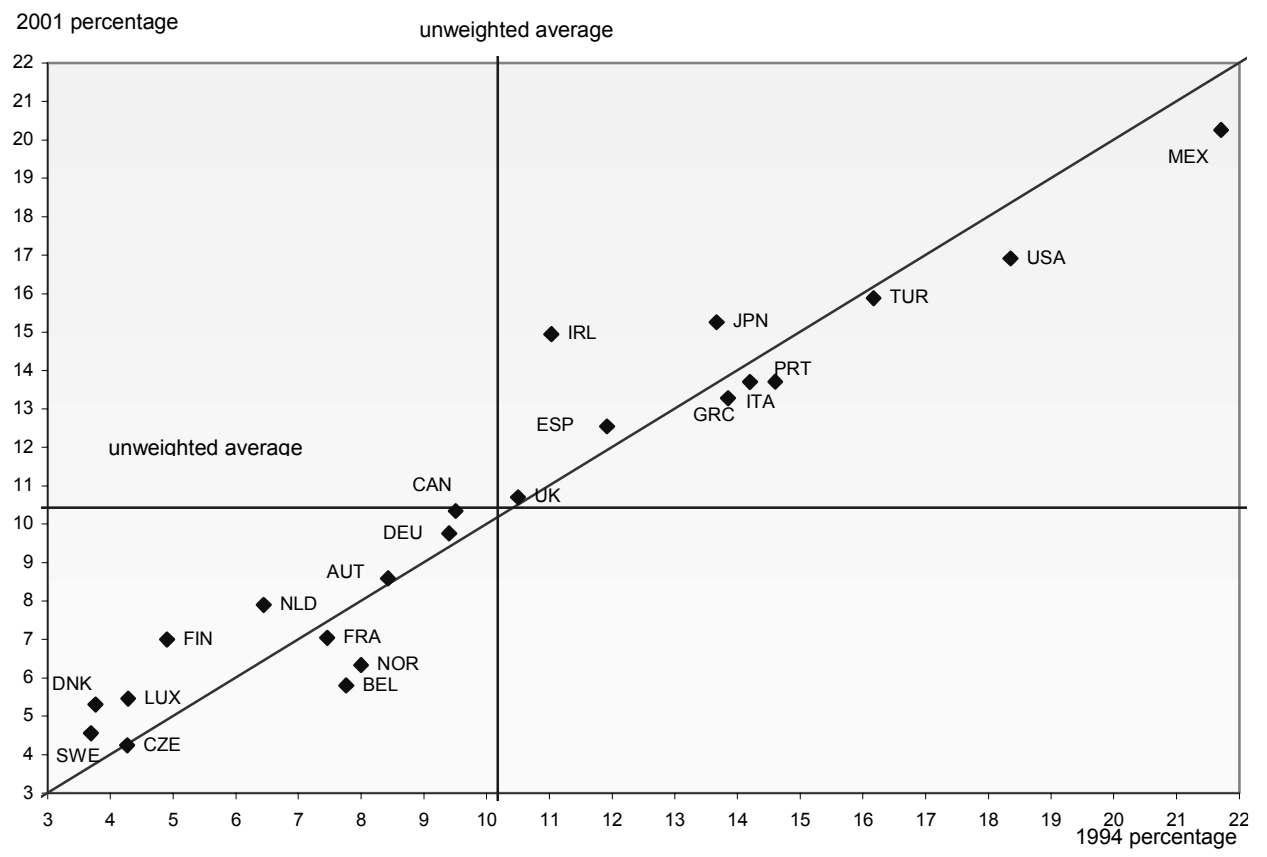

a) Calculated as the proportion of the population with income below 50 per cent of the current median income.

b) 1983-1994 for Austria and Denmark, 1983-1995 for Sweden, 1984-1995 for Italy, 1985-1994 for Japan, Luxembourg,

Netherlands, Spain and United Kingdom, 1985-1995 for Belgium and Canada, 1986-1995 for Finland and Norway,

1987-1994 for Ireland and Turkey, 1988-1994 for Greece, 1990-1995 for Portugal.

c) 1994-2000 for France and Japan, 1994-2002 for Mexico and Turkey, 1995-2000 for Canada and Norway, 1995-2001 for Belgium, Finland, Italy, Portugal and Sweden, 1996-2002 for Czech Republic.

Sources: Förster and Mira d'Ercole (2005), Luxembourg Income Study (LIS) data set, European Community Household Panel (ECHP) data set and Cross National Equivalent Files (CNEF) data set. 
Figure 4. Relative poverty risk profile by age group Waves 1994-2001
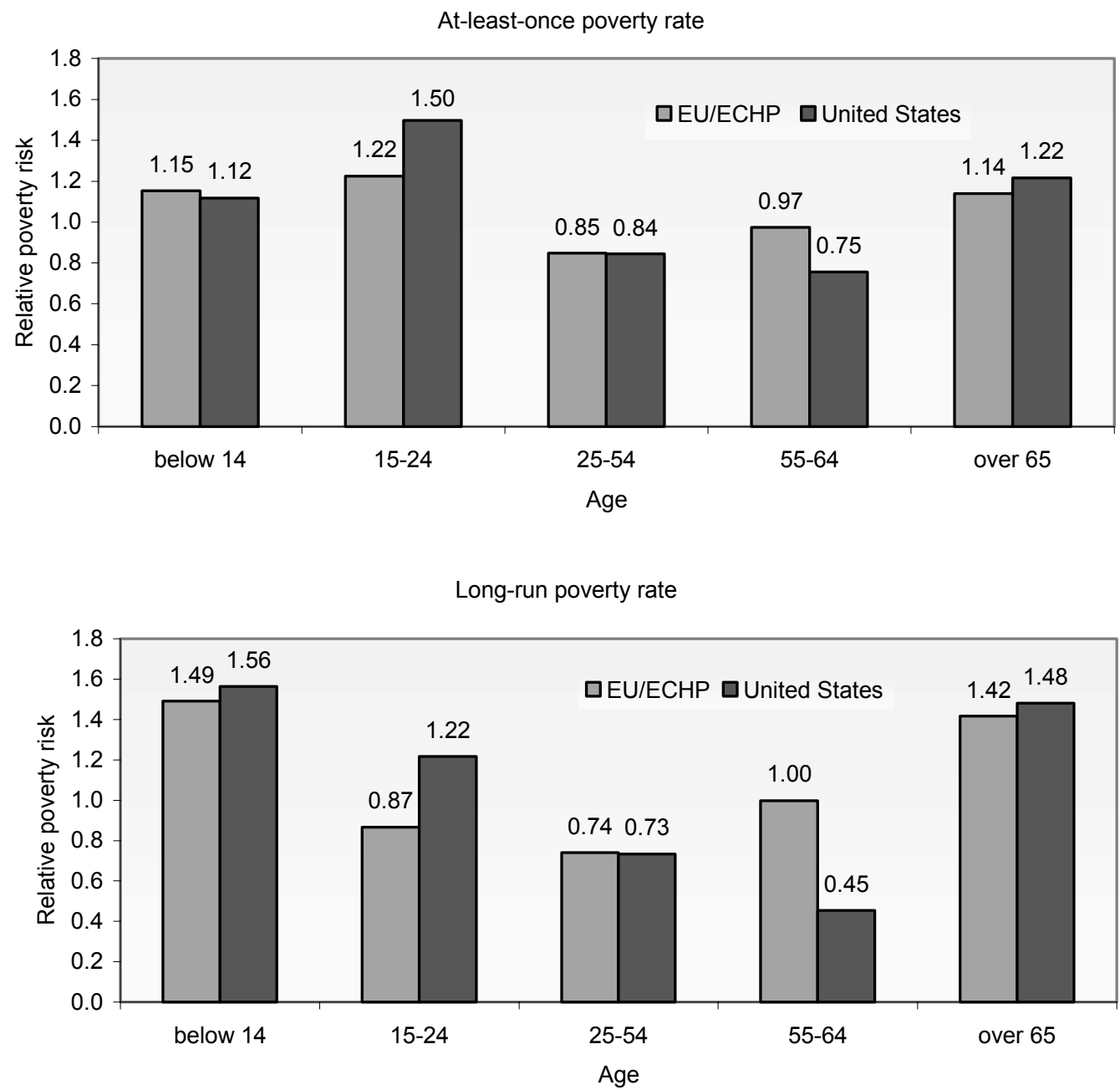

Source: European Community Household Panel (ECHP) data set and Cross National Equivalent Files (CNEF) data set. 


\section{WORKING PAPERS}

The full series of Economics Department Working Papers can be consulted at www.oecd.org/eco/Working_Papers/

499. Improving Public-Spending Efficiency in Czech Regions and Municipalities (July 2006) Philip Hemmings

498. Policies to Promote Innovation in the Czech Republic (July 2006) Alessandro Goglio

497. Getting Education Right for Long-Term Growth in the Czech Republic (July 2006) Alessandro Goglio

496. Assessing the 2005 Czech Proposals for Pension Reform (July 2006) Philip Hemmings and Edward Whitehouse

495. Poland's Education and Training: Boosting and Adapting Human Capital (July 2006) Paul O’Brien and Wojciech Paczynski

494. The Rates and Revenue of Bank Transaction Taxes (July 2006) Jorge Baca-Campodónico, Luiz de Mello and Andrei Kirilenko

493. Nothing Ventured, Nothing Gained: The Long-Run Fiscal Reward of Structural Reforms (July 2006) Peter Hoeller and Claude Giorno

492. Ireland's Housing Boom: What has Driven It and Have Prices Overshot? (June 2006) Dave Rae and Paul van den Noord

491. Boosting Competition in Ireland (June 2006) Dave Rae, Line Vogt and Michael Wise

490. Factors Behind Low Long-Term Interest Rates (June 2006) Rudiger Ahrend, Pietro Catte and Robert Price

489. The Fiscal Challenge in Portugal (June 2006) Stéphanie Guichard and Willi Leibfritz

488. Are House Prices Nearing a Peak? A Probit Analysis for 17 OECD Countries (June 2006) Paul van den Noord

487. Maintaining Switzerland's Top Innovation Capacity (June 2006) Florence Jaumotte

486. Employment Patterns in OECD Countries: Reassessing the Role of Policies and Institutions (June 2006) Andrea Bassanini and Romain Duval

485. Brazil's Fiscal Stance During 1995-2005: The Effect of Indebtedness on Fiscal Policy Over the Business Cycle (May 2006) Luiz de Mello and Diego Moccero

484. Realising the Oil Supply Potential of the CIS: The Impact of Institutions and Policies (May 2006) Rudiger Ahrend and William Tompson 
483. Summary of a workshop on global convergence scenarios: structural and policy issues (May 2006) Nick Vanston

482. Revised OECD methods for supply-side and medium-term assessment: a capital services approach (July 2006) Pierre-Olivier Beffy, Patrice Ollivaud, Pete Richardson and Frank Sédillot

481. Balancing health care quality and cost containment: the case of Norway (February 2006) Alexandra Bibbee and Flavio Padrini

480. The ageing challenge in Norway: ensuring a sustainable pension and welfare system (February 2006) Benoît Bellone and Alexandra Bibbee

479. Strengthening innovation in the Netherlands: Making better use of knowledge creation in innovation activities (February 2006) David Carey, Ekkehard Ernst, Rebecca Oyomopito and Jelte Theisens

478. How to sustain growth in a resource based economy? The main concepts and their application to the Russian case

(February 2006) Rudiger Ahrend

477. Projecting OECD health and long-term care expenditures: What are the main drivers? (February 2006)

476. Alternative measures of well-being (January 2006) Romina Boarini, Åsa Johansson and Marco Mira D'Ercole

475. Recent house price developments: the role of fundamentals (January 2006) Nathalie Girouard, Mike Kennedy, Paul van den Noord and Christophe André

474. Reforming federal fiscal relations in Austria (January 2006) Andrès Fuentes, Eckhard Wurzel and Andreas Wörgötter

473. Product market competition and economic performance in France Concurrence sur les marchés de produits et performance économique en France (January 2006) Jens Høj and Michael Wise

472. Product market reforms and employment in OECD countries (December 2005) Giuseppe Nicoletti and Stefano Scarpetta

471. Fast-falling barriers and growing concentration: the emergence of a private economy in China (December 2005) Sean Dougherty and Richard Herd

470. Sustaining high growth through innovation: reforming the R\&D and education systems in Korea (December 2005) Yongchun Baek and Randall Jones

469. The labour market in Korea: enhancing flexibility and raising participation (December 2005) Randall Jones

468. Getting the most out of public-sector decentralization in Korea (December 2005) Randall Jones and Tadashi Yokoyama

467. Coping with the inevitable adjustment in the US current account (December 2005) Peter Jarrett

466. Is there a case for sophisticated balanced-budget rules? (December 2005) Antonio Fatás 